doi:10.7592/TF10.geo

\title{
Geopeitus - 21. sajandi harrastus mängu žanriraamis ja väljaspool $^{1}$
}

\author{
Mare Kalda
}

"Lähem vaatlus näitab, et tänapäevane infoühiskond siiski ei nivelleeri mängude folkloorset, loomulikku ja variandirikast olemasolu" (Vissel 1995, 298).

\begin{abstract}
Teesid: Alates 2000. aastast harrastatakse maailma eri paigus geopeitust - varanduste otsimise mängu, mille käigus navigeerimis- ja infotehnoloogia abil peidetakse ja otsitakse aardeid. Peidikud asetsevad füüsilise ruumi varjatud punktides, osalejate poolt ühiselt hallatav ja pidevalt uuendatav informatsioon on aga üles laetud internetti, kus toimub ka mängualane suhtlus. Uurimuse ülesandeks on kõrvutada geopeitust juba ludoloogia klassikas esile toodud tunnustega, kuid esitleda muidki kategoriseerimisvõimalusi, mida hobi senistes käsitlustes on rakendatud. Mängu kui tegevusžanri tunnuste üle arutledes on selgitatud aardeotsimisharrastuse eripära, et mitmekesistada folkloristlikku teadmist varandusteteema (traditsioonilise tegude ja juttude aine) uudse väljendumisviisi osas infoajastu kultuurisituatsioonis. Artikkel keskendub eelkõige geopeitusele Eestis, kuid pakub sissevaateid ka rahvusvahelisse mängu.
\end{abstract}

Märksõnad: geopeitus, kõikjalolevad mängud, mäng kui folkloorižanr

${ }^{1}$ Artikkel on seotud kultuuriuuringute projektidega SF 0030181 s08 ja ETF 8137. 


\section{Uus algus}

2002. aasta kevadel sain e-kirja koos Eestis leiduvate aarete lingitava loendiga. Olles folkloristina juba aastaid uurinud peidetud varanduse jutte, arvasin, et digikaartide ja nendele andmete kandmise oskuse leviku tulemusel on kaardistatud rahvapärimuses teadaolevad aardekohad. Kahtlused ei leidnud kinnitust. Nimestik koosnes täiesti uutest peidikutest, mis olid moodustatud hiljuti alanud aardepeitmise ja -otsimise mängu raames.

2000. aastal USAs Oregoni osariigis alanud ja seejärel maailma eri paigus hoogsalt käima läinud geocaching ${ }^{2}$ inspireeris sama katsetama Eestis, kus kohaliku geopeituse esimene aare peideti 10 . veebruaril 2001 (Veenpere 2002; vt ka HE-aare 2001).

Mängu käigus peidetakse laegas esemetega, määratakse peidukoha geograafilised koordinaadid ning informeeritakse potentsiaalseid kaasmängijaid aarde asukohast ja muudest tunnustest. Igaüks võib soovi korral peidiku üles otsida, aardest midagi endale võtta, midagi asemele jätta ning teha sissekande oma külastuse kohta nii laekas olevasse külalisraamatusse (mängu sõnavaras logiraamatusse) kui ka mängu koduleheküljele internetis, kus toimubki harrastuse koordineerimine kõigi osalejate ühisel osavõtul. Harrastajad loovad ja arendavad seal oma tegevuse infoplatvormi: registreeritud kasutajatena teatavad nad uutest aaretest ja varustavad uute aarete kirjeldusi asjakohase teabega, kirjutavad ülevaateid olemasolevate aarete otsimiskordadest, arutlevad temaatiliselt struktureeritud foorumirubriikides nii geopeituse käigus tekkivate üldisemate küsimuste (näiteks mängureeglid ja uute tulijate kaasamine) kui ka konkreetsete aaretega seonduvate asjaolude üle. Sagedane on infotehnoloogiliste rakenduste tutvustamine ning vaagimine kasutaja- ja arendajakogemuste vahendamise teel.

Aardeotsimismäng 21. sajandi versioonis on uuendatud vormis asjadepeitus, mis käivitub inimlikust mängimislustist ja lisastiimulite loomise vajadusest. Hobi näib vastavat oma ajakasutust kontrollivate inimeste huvidele, kes soovivad testida infotehno-

${ }^{2}$ Kogu mängualane informatsioon koos harrastuse saamisloo tutvustuse, reeglite, võimaluste ja viidetega leidaolevatele aaretele (caches) leidub kesksel, kõigi geopeitjate poolt külastataval ja täidetaval koduleheküljel geocaching.com. Mitmesugused teemade kaupa struktureeritud foorumid, kus osalejad aktiivselt arutlevad mängu käigu ning harrastades omandatud kogemuste üle, on leitavad http://forums.groundspeak.com/GC/. 


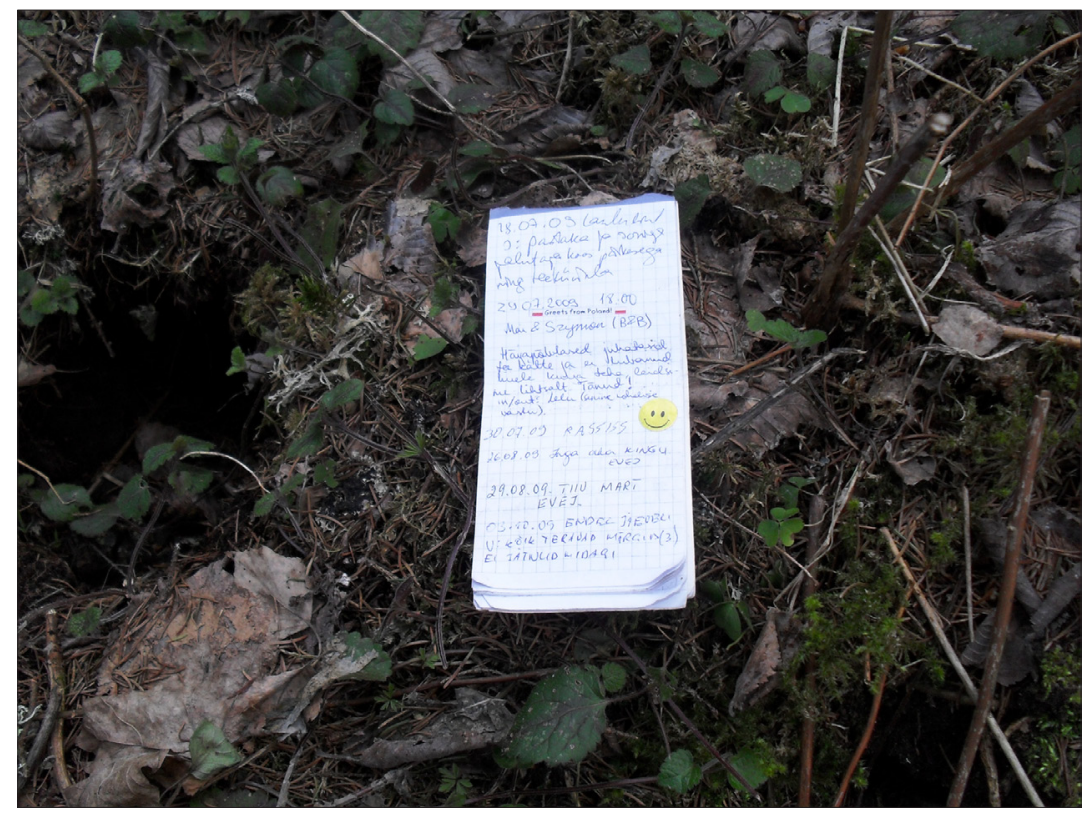

Foto 1. Logiraamat aardes. Ain Kalda foto 2010.

loogilisi lahendusi väljaspool otseste tööülesannete täitmist ja kes varieerivad mänguliselt kõikvõimalikke mobiilseid rakendusi. Elementaarne peitmise-otsimise idee, traditsioonilises mängudeliigituses üks peitemängudest (Kalmre 2005, 172), uueneb ja kohandub informatsiooniühiskonna tingimustes. Aardelaegaste peitmiseks, online-aardekirjelduste loomiseks, huvipakkuvate peidikute avastamiseks ja mängukordade registreerimiseks ehk aardeotsimise raportite kirjutamiseks kasutatakse tänapäevaseid navigeerimisja infovahendeid. Osalemine on vabatahtlik ja demokraatlik, kuid nagu iga mängu puhul, tuleb järgida mängu reegleid.

Geopeituse eelsel ajastul olid minu uurimisallikateks olnud 150 aasta jooksul jäädvustatud rahvajutud, mida täiendasid sadakond meediaartiklit, kodulookirjutus, mõned katked erakirjades ning lugude ilukirjanduslikud kasutusnäited. Aardepärimusega tegelemise alguses pidasin temaatilist juttuderühma puhtalt kujutlusi ja soovmõtlemist väljendavateks lugudeks. Lähem tutvumine 
arhiivitekstidega, kaasaegsed tähelepanekud ja interneti kaudu leviva ainese jälgimine tõi korrektiive: taipasin, et aardefolkloor kujutab endast faktide, traditsioonilise teabe, uskumuste, fantaasia ja rahvapäraste tõlgenduste keerukat põimingut, kuhu kuuluvad ka tegelikult tehtud teod ja läbielatud olukorrad.

Klassikaliste aardemuistendite puhul ei näinud ma mingit võimalust teema sooritusliku tasandi kogemiseks. Folkloristlike välitööde käigus olen külastanud muistenditega seotud paiku, mille otsimine maastikul sarnaneb rohkem loodusturisti või matkaja liikumisega - see on külastaja, vaatleja, mitte tegija kogemus. Uus aardeotsimismäng geopeituse nime all ahvatles (esialgu lihtsalt harrastajana) proovima, millega on tegu. Aprillis 2002 läksime oma otsijaterühmaga avastama meie esimest aaret, mis asus juhuslikult mulle tuttavas marjametsas. Otsinguid saatis edu, olime veebruaris 2002 peidetud Aastapäeva aarde (vt Aastapäeva) kuuendad leidjad. Nüüdseks kõnealust aaret enam pole, kuna see tõenäoliselt hävis lageraie käigus 2007. aastal. Hobi osutus köitvaks ja kaasahaaravaks, kuna pakkus võimalust teha midagi senisest erinevat. Ühtlasi seostus immersiivne tegevus minu silmis aardepärimuse uurimiskogemusega - tajusin siirdumist aarete peitmiselt kui ressursside püsimist kindlustavalt praktikalt ja varanduste otsimiselt kui kasusaamise lootusest ajendatud ettevõtmiselt uuele tasandile.

Sellest, missuguses arengujärgus on geopeitus Eestis, saab ülevaate, külastades geopeitus.ee statistikalehekülge (http://www. geopeitus.ee/statistika), mis uute aarete ning seniste aarete logiteadete lisandudes pidevalt uueneb. Samuti saab sealt teada, kui suur on vaadeldaval ajahetkel registreerunud kasutajate hulk ning kui aktiivsed nad üldjoontes on. Registreeritud kasutajana sisse loginud geopeitjad näevad lisaks nimetatutele veel detailsemat infot, näiteks iseenda ja kaaslaste skoori ja otsimiste loendit, samuti leidude levikukaarte, foorumipostituste ajalugu jne. Graafikud edastavad mängu dünaamikat: logiteadete, sõnumite ning uute aarete lisandumise põhjal on näha, kuidas 2008. aastani on mäng arenenud ühtlases tõusvas joones, millele järgnes märgatav hüpe 2009-2010. 2013. aasta alguskuude seisuga oli peidus 1675 aaret (389 olid arhiveeritud ehk mitte enam leitavad). Aktiivsemaid osalejaid on ligi kolmsada, kuigi kasutajakonto on teinud paljud (suurusjärk püsib - mõned varem aktiivsed harrastajad on küll lõpetanud, kuid nende asemel jätkavad uued). 211 registreerunut pole siiski geopeituriks 


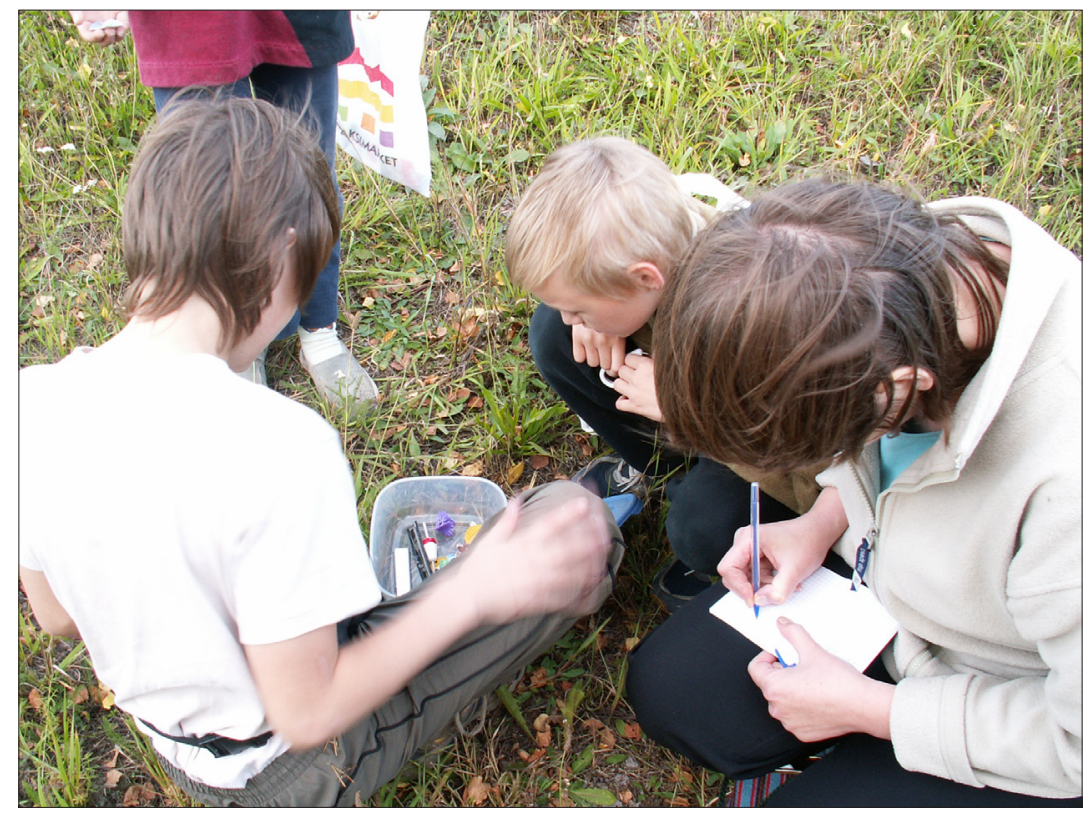

Foto 2. Sissekande tegemine paberlogiraamatusse. Ain Kalda foto 2005.

hakanud, mida võib öelda ka leiuskoori 1-2 puhul. 131889 otsimisraportit teatavad leidmisest, 11424 leidmata jäämisest. Geopeituse andmekogu sisaldab hulgaliselt pilte, mida 2013. aasta märtsis oli 23 814. Üle 19000 postituse on tehtud erinevatesse foorumitesse.

Rahvusvahelise geopeituse kesksel koduleheküljel geocaching. com, kus suurusjärgud on kordades suuremad, selline üksikasjalik dünaamika nii kergesti esile ei tule. 500000 aarde piir ületati 31. detsembril 2007. 2010. aastal oodati mängu miljonendat aaret. See sai teoks 8. märtsil 2010, mille kohta Groundspeak - veebikeskkonda geocaching.com haldav organisatsioon - avaldas vastava pressiteate (http://support.groundspeak.com/index.php?pg=kb.page\&id=213). 28 . veebruariks 2013 on rahvusvahelises mängus 2 miljonit aaret. Kuu aja jooksul tehakse veebikeskkonnas geocaching.com umbes 5,9 miljonit logisissekannet ja harrastajaskonna suurusjärk on hinnanguliselt rohkem kui neli miljonit geopeitjat. 


\section{Kuidas uurida geopeitust?}

Geopeitus kujunes mulle harrastuseks, mis annab ainet folkloristlikuks uurimiseks. 21. sajandi metoodikate mitmekesisuses on sallitud ka olukord, kus kogukonda vaatleb uurija, kes ise sellesse kuulub või mille liikmeks ennast peab. Seetõttu pooldan Leon Andersoni autoetnograafilist metoodikat. Uurimisviisi iseloomustavate tunnuste kohaselt on uurija vaadeldava kogukonna liige, tema positsioon on avaldatud tulemustes esil ning uuritavat nähtust püütakse mõista laiemas sotsiaalses kontekstis (Anderson 2006, 373). Minu vaade uurimisainesele on vaade seesolija perspektiivist.

Töös püüan kasutada niisugust sõnavara, mis võimalikult tabavalt kirjeldaks mängu etappide sooritamist vahelduvalt online-keskkonnas ja füüsilises tegelikkuses või emba-kumba mõne tehnorakenduse toel teineteisesse paigutades. Geopeituse internetilehekülge käsitlen kui harrastuse online-keskkonda, infoplatvormi või mõnevõrra poeetilisemalt - virtuaalset kodu. Kuivõrd viitan online arvutimängudele või teistele virtuaalsetele keskkondadele, kasutan ka virtuaalse maailma mõistet, mis aga geopeitusele kohandades nõuaks jutumärke ja pikemat seletamist. See, mida geopeituses ei tehta arvuti abil internetis, toimub füüsilises maailmas, füüsilises tegelikkuses. ${ }^{3}$ Mängužanr, mängulisuse kategooria eeldab tähelepanu pööramist vastandustele päris- ja mängu- või päris- ja virtuaalne, mäng ja mitte-mäng. Sellega seoses refereerin töid, kus vaagitakse mängu tunnuseid ja omadusi. Insaideri vaatepunkt toob kaasa harrastuse omamõisted, millest loobumiseks ma põhjust ei näe (eestikeelse omaterminoloogia juurde juhatab Sõnastik [2001-2013]).

Uute aarete koostamine ja kaasharrastajate informeerimine, otsimiskäikude ülevaated, nagu ka mitmekülgne reflektsioon foorumites, moodustab mitmekülgse ja huvitava andmekogu, mis kajastab mängus toimuvat, ühtlasi tulevad esile ja satuvad arutluse alla osalejate vaated maailmale geopeituse ümber. Tähtis aspekt seejuures on, ja seda rõhutavad mitmed geopeituse analüütikud, kuidas mängu kajastavate internetilehekülgede sisu toodavad ka-

${ }^{3}$ Vrd teiste geopeitusest kirjutajate mõistekasutust; Gill Clough (2010): virtual spaces - physical spaces; Kenton O'Hara (2008): online - in situ; Lasse Gram-Hansen (2009): technological domain - physical domain; Katharine Willis (2010): digital information - real terrain; Maarit Kinnunen (2010): virtuaali maailma - reaali maailma ja virtuaalinen tila - todellinen tila. 
sutajad ise (Gram-Hansen 2009; Clough 2010, 33-34; Ihamäki 2012, 144). Oluline on mitte ainult online-sisu loomine osalejate endi poolt, vaid loovuse moment kaasharrastajatele kogemuste võimaldamisel füüsilises maailmas, kuna geopeitjad pole pelgalt kohakogemuste tarbijad, vaid loojad kogu harrastajaskonna heaks (O'Hara 2008, 1177). Mängualane informatsioon koondub niisiis osalejate ühiste jõupingutustega harrastuse virtuaalsesse keskusse ja on selle külastajatele vabalt kasutatav.

Väidan, et folkloristliku allikakriitika seisukohalt on tegu olukorraga, kus uuritava nähtuse väljendumiskordi ehk variante ei tulegi eraldi koguda, vaid need kogunevad ise, täpsemalt muidugi harrastajaskonna liikmete käe läbi. Pean ühise huvi pinnalt lähtuvate tegude kajastusi ühiselt kujundatavas virtuaalses keskkonnas väärtuslikuks materjaliks niisugusena, nagu need on sinna postitatud. Sama seisukohta väljendab Second Life'i, ühe suhtlemiseks ja enese alternatiivseks esitluseks mõeldud virtuaalmaailma, uurija Tom Boellstorff, kes väärtustab sealsete asukate tegusid ja ütlusi tolle maailma kohta kui igati legitiimseid andmeid (Boellstorff 2008, 61). Internetietnograafia (samas, 60-86) on toimiv meetod lehekülgede geopeitus.ee ja geocaching.com kui allikate kirjeldamiseks, et saada selgust spetsiifilise tegevuse ning selle käigus konstrueeritava teadmise osas. Põhimõtteliselt leiduvad näiteks keskkonnas geopeitus.ee kõik vastused küsimustele, kuidas Eesti geopeitjad tegutsevad, mida kogevad, kuidas otsinguid planeerivad, mis rõõmustab ja mis kutsub esile negatiivset vastukaja, kui intensiivselt hobiga tegeldakse, missuguseid mängijataktikaid viljeletakse, missugused aarded on mängus, kuidas need paigutuvad senistesse kohasuhetesse, millised on logikirjutamise konventsioonid, kuidas geopeitjad omavahel suhtlevad jne. Internetietnograafiat täiendavad osaleva uurija tähelepanekud.

Kas ja mil määral kujutab geopeituse kodulehekülg endast omaette virtuaalset maailma? Või kas geopeituses tekib mängumaailm - tegudest füüsilises keskkonnas koos struktureeritud informatsiooni ning kogukonnaliikmete omavahelise online-suhtlusega? Kas geopeitus toimub "tavalisest" elust eraldatud mänguruumis, mis "kas materiaalselt või ainult ideaalselt, kavatsuslikult või endastmõistetavalt on juba ette tähistatud" (Huizinga 2003 [1938], 19)? Tingimustes, mil meelelahutuses teevad võidukäiku arvutimängud, on osa kompuutertehnoloogia kasutamist eeldavaid mänge seatud hõlmama lisaks online-sooritustele nurki ja nurgakesi füüsilises 
maailmas, digitaalselt kättesaadav informatsioon koha peal kaasas. Erineva taustaga ludoloogid, digikommunikatsiooni eksperdid ja disainerid on juba välja töötanud mõisteaparatuuri ja meetodid niisuguste mängude analüüsimiseks, et kirjeldada segunenud reaalsust (mixed reality; vt nt Milgram, Kishino 1994; Constanza, Kunz, Fjeld 2009), kõikjalolevaid mänge (pervasive / ubiquitous games; vt nt Montola, Stenros, Waern 2009), laiendatud tegelikkust (augmented reality; vt nt Bimber, Raskar 2005). Füüsilises maailmas kehaliselt kogetav ühelt poolt ning virtuaalses keskkonnas tehtavad toimingud teiselt poolt kuuluvad tõepoolest igapäevasesse geopeitusesse, vahelduvad ja põimuvad - geopeitus on tänapäevases mängudeliigituses kõikjalolev mäng (Montola, Stenros, Waern 2009, 31-33). Ent ka Pirita Ihamäki mõjub veenvalt, kui ta rõhutab geopeituse segunenud reaalsuse omadusi: segunevad tegelik (real) ja internetikeskkond, mis mängu seisukohalt täidavad kumbki erinevaid funktsioone; info- ja kommunikatsioonitehnoloogia vahendusel ületatakse traditsioonilisi mänguruume, mille tulemusel tekib uus, laiendatud keskkond, kus kasutaja tegelik (real) ümbrus muutub kogu mängu oluliseks komponendiks (Ihamäki 2012, 141). Segunenud reaalsust loovad interaktiivsed kaardid nutitelefonis, võimalused raja visualiseerimiseks GPSi ekraanil, teekonnavideo pardakaameras, kuid ka elektroonilised seadmed aaretes, mis teatud manipulatsioonide tagajärjel käivituvad. Nagu näha, kirjeldavad lähenemine kõikjaloleva mängu mõiste kaudu ja segunenud reaalsuse metoodika tegelikult sama ilmingut. Carsten Magerkurth koos kaasautoritega resümeerib, et kõikjalolevates mängudes integreeritakse arvuti kaudu ligipääsetav virtuaalne domeen tegeliku (real) maailma füüsiliste ja sotsiaalsete aspektidega (Magerkurth et al. 2005 , 2). Igal juhul on tegu mängude valdkonnaga, mille uurimise meetod eeldab kaasategemist (Aarseth 2003, 5, 7; Stenros, Waern, Montola 2012, 345-346).

Uurimuse ülesandeks on vaagida geopeituse mängu-olemust, kuid esitleda ka muid kategoriseerimisvõimalusi. Iseloomustan lähemalt tegevusse haaratud elemente ja sooritusi. Mängu kui tegevusžanri tunnuseid silmas pidades püüan selgitada aardeotsimise kui harrastuse eripära, et mitmekesistada folkloristlikku teadmist varandusteteema (traditsioonilise tegude ja juttude aine) ühe väljendumisviisi osas infoajastu kultuurisituatsioonis.

Keskendun eelkõige geopeitusele Eestis, kuid toon näiteid ka maailma teistest regioonidest. Kohaliku mängu kestmise teisel 
aastal avaldati kuukirjas Arvutimaailm Eesti geopeituse tutvustus (vt Veenpere 2002), mis rõhutab ilmset seost infotehnoloogiaga. Harrastuse mõningast lähedust turismile näitab artikkel ajakirjas Reisimaailm (Einama 2004). Lisaks nimetatutele on Eesti geopeitusest juttu tehtud kohalike meediaväljaannete jooksvates uudislugudes ja ajakirjandusliku eksperimendi korras Eesti Televisiooni Terevisioo$n i$ rubriigis 23. mail 2003 (koos aardepeitmisega; vt Terevisiooni). 2007. aastast pärineb sissevaade muistendite kasutamisest geopeituses kui rahvajuttude rakendamine uues kontekstis (Kalda 2007).

\section{Mis on geopeitus?}

Geopeitus.ee-s leiduva definitsiooni kohaselt on geopeitus "värskes õhus mängitav aardeotsimismäng, milles osalejad kasutavad GPS-i, muid navigeerimistehnoloogiaid või täpseid maakaarte, et peita ja otsida spetsiaalseid geopeituse aardeid”. Mängude hulka liigitavadki geopeitjad oma tegevuse kõige sagedamini, rõhutades harrastuse mängu-olemust, näiteks ühist tegevust korrastavates aruteludes või kui mõnes foorumiteemas sõnavõtud liiga tõsiseks kisuvad. Vähemalt Eestis on see nii. Kaasategijad reflekteerivad elavalt oma tegevust mitme kandi pealt, samuti on diskussioone tekitanud küsimus, mis on geopeitus. Maikuus 2005 arutleti selle üle rahvusvahelises foorumis võrdlemisi kirglikult (vt Is Geocaching A ... sport). Postitustes toodi välja nii spordi, mängu kui ka ajaveetmise definitsioone ning loetleti omadusi, mille poolest geopeitus sobitub või ei sobitu eelistatud kategooriasse. Geopeitja Glenn jagas teistega oma Google'i otsingu tulemust, mis sisaldas umbes 60 definitsiooni või definitsiooni moodi määratlust, mis geopeitus on või ei ole. Postitajate tähelepanu pälvisid võistlus versus võistluse puudumine, kehalist pingutust nõudev sooritus versus lihtne jalutuskäik, skoori tagaajamine versus tasapisi edenemine. Diskussiooni peeti sellest hoolimata, et juba 2002. aastal oli samalaadses mõttevahetuses välja pakutud RASH, akronüüm sõnadest Recreational Activity Sport Hobby (vt RASH), mida nii mõnedki postitajad hea sõnaga meenutasid (tõsi, toonases foorumis oli küll tuliseid akronüümivastaseid). Mõned kirjutajad rõhutasid kategoriseerimise asemel hoopis tegemise lõbu.

Päris ühel meelel, mis geopeitus on, ei olda erinevatest vaatepunktidest lähtuvates ja erinevalt sõnastatud uurimisülesannetega käsitlustes. Geopeituse määratlemisel kohtab erinevaid üldmõisteid, 
mille hulka kuuluvaks või mida esindavaks seda peetakse. Kõige tavalisem on mäng üldmõistena (paari erandiga), kuid esiplaanile seatakse geopeituse analüütiline definitsioon mõnes spetsiifilises kontseptuaalses raamistikus. Mõisteraami mõjutab nähtuse suhteline uudsus - äratundmine, millega seni kogetust geopeitus õigupoolest kõige ilmsemalt seostub, alles vormub. Oma mõju avaldab institutsioon või valdkond, mida uurija esindab. Sellest sõltub, missuguse tegevusala ja teaduse erikeeles ning kontekstis ta geopeitusest kõneleb. Kolmandaks võib geopeituses avastada elemente, omadusi ja toimimisviise, mis tõepoolest eemalduvad teistest (tuntud) mängudest ja teevad geopeituse eriliseks.

Meediaväljaanded asetavad oma sõnumid informatsioonitehnoloogia interpretatsiooniraamistikku. Juttu on uuest, kõrgtehnoloogilisest, spetsiaalseid elektroonilisi vahendeid ja nende kasutamise oskust nõudvast harrastusest. ${ }^{4}$ Tehnoloogiasõnavarale liidavad toimetajad siiski ka viited vanadele tuttavatele tegevustele, kaasa arvatud mängudele. Kohe, kui mäng Eestis käivitus, avaldas Eesti Päevaleht uudisloo "Kõrgtehnoloogiline peitusemäng GPSi abil" (Päevaleht, 25. jaanuar 2001). Huvitav on see, et kuigi geopeitus on globaalne üritus ja selle kajastuses on väga palju sarnast eri maades, ilmneb liigitamisel-seostamisel siiski iseärasusi. Näiteks saksakeelne meedia defineerib rahvusvahelist nimetust geocaching eelistatult maastikumängu Schnitzeljagd kaudu, mis mõistena erineb päris-aareteotsimisest (vt Sadewasser 2007, 14 jj; Telaar 2007, 1, 6, 17). Treasure hunt ingliskeelsetes pealkirjades tähistab teatavasti ka mänguvälist pärisaareteotsimist. Eesti-siseselt on geopeituse ülaltoodud definitsioon mõeldud pigem autsaideritele asjast ettekujutuse andmiseks, harrastajatele on see midagi enamat kui maastikumäng; harva seostatakse teda kunagiste luurekatega (mängijate niisugusest omamõistest vt Vissel 1995, 277-279; geopeitusega ühenduses siiski: http://www.blondiinmolly.

${ }^{4}$ Geocaching.com üks alaosa koondab jooksvalt linke maailma eri paigus ilmuvatele meediaväljaannetele, mis geocachingut tutvustavad. Seal leiduvate viidete toel esitan vaid mõned pealkirjanäited: The thrill of the hunt - with GPS technology, Medill Reports, Chicago 17. X 2012; Techies go treasure hunting, North Devon Journal, 12. IX 2012; Hi-tech treasure hunt, The Telegraph 14. II 2011; Treasure hunter go high-tech, using GPStechnology in quests to discover hidden caches, Columbia Daily Tribune 24. VII 2011; High-Tech-Schnitzeljagd nach der blauen Brotzeitdose, Die Welt 6. II 2005; Hightech-Schnitzeljagd: Schatzsuche mit GPS-Hilfe, 20. III 2006 Spiegel-Online jne. 
com/2012/09/geocatching-geopeitus.html). See-eest nimetatakse aardeotsimis- ja maastikumängudeks kõhklematult mitmesuguste festivalide jm pidustuste raames korraldatud atraktsioone (Vabrit 2002, 72; Muuseumiöö 2011).

Analüüsivate käsitluste autorid eksponeerivad oma uurimisainest põhimõtteliselt samade kategooriate kaudu nagu meedias tavaks, kasutatakse ootuspäraseid ja asjakohaseid nimetusi mäng ja harrastus ning veelgi üldisem tegevus. Näiteks Kenton O'Hara iseloomustab konverentsisarja "Human Factors in Computing Systems" ettekandes geopeitust kui aardejahti või tegevust tehnoloogia toel (technology-enabled activity / treasure hunt; O'Hara 2008, 1177), kusjuures vaatluse keskmes on sooritused ja osalemismotiivid asukohapõhises tegevuses laiemaltki. Gill Clough defineerib geopeituse samuti GPSi suunamisel toimuva aardejahi üheks vormiks ( $a$ form of GPS-guided treasure hunt; Clough 2010, 33). Kuna ta tegeleb mitteformaalse õppe arendamisega, toob ta nähtavale teadmiste loomise ja omandamise aspekti, mis harrastuses tõepoolest ilmsiks tuleb. Nii peites kui ka otsides uurivad geopeitjad mitmesugust kohapõhist jm liiki informatsiooni, tehniliste oskuste edendamisest (navigeerimine, mobiilne arvutikasutus, uute kasutajaliideste testimine jne) rääkimata. Aardepeitja, kes tahab kaaslastele teavet jagada, töötleb seda eelnevalt, teeb valikuid, uurib allikaid. Otsijad tutvuvad pakutud andmetega ning omandavad unikaalset lisa koha peal käies. Harivat potentsiaali on näha eriti mõistatusaarete puhul, mille idee, teostamine ja hiljem lahendus koos hüpoteeside kontrollimisega füüsilisel maastikul nõuavad visadust ja/või parajat puremist - mõistatuste lahendusteede otsimist, arvutusi, sõnade etümoloogiate jälitamist, rahvapärimuse meenutamist, taimetundmist, koodide lahtimuukimist, salakirja võtme äraarvamist, raskel maastikul hakkamasaamist. Osutan mõnele näitele Eesti geopeitusest. Näpunäide, üks Tartu linna-aaretest, eeldab leidjalt rahvapäraste sõrmenimede tundmist; Kes elab metsa sees? - puuliikide määramist lehtede järgi; Enigma - krüpteeritud info dešifreerimist; Puhatu jts - raskel rabamaastikul liikumist nagu ka looduskaitselistest piiranguaegadest kinnipidamist. Lisaks detailsete ülesannete lahendamisele õpetab nii mõnigi geopeituse aare valima olukorrale vastavat toimimisviisi. Näiteks keeruliste aarete peitmise poolest kogukonnas juba kuulsust kogunud [geokrahv] ${ }^{5}$

${ }^{5}$ Mängijate registreeritud kasutajanimedele viitan nii, nagu on tavaks geopeitus.ee-s, st väikese algustähega ja nurksulgudesse paigutatult. 


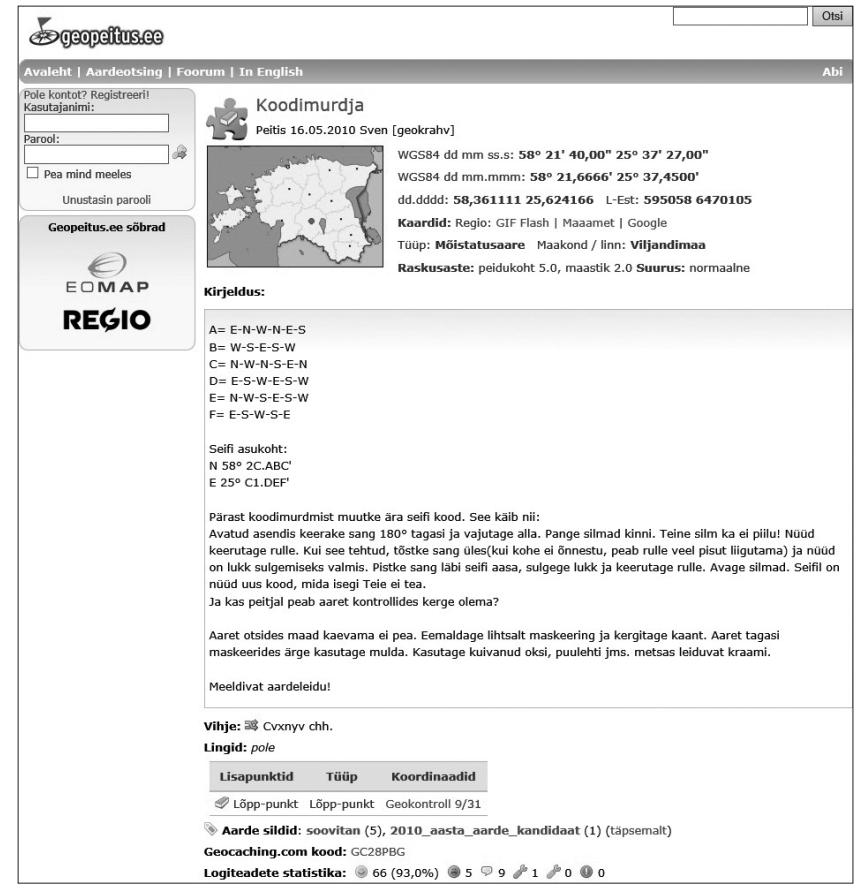

Joonis 1. Üks geopeituse mõistatusaaretest (vt Koodimurdja). Ekraanipilt geopeitus.ee-st.

juhendab kaasgeopeitureid GK 100 aarde saatesõnas muuhulgas: "Õppige pilti kokku panema." (vt GK 100.) Selle konkreetse ja teistegi aarete logides leidub tunnistusi, mida kellelgi õppida õnnestus.

Asjaolu, et geopeitust harrastades omandatakse uusi teadmisi aareteotsimisel külastatavate paikade ja objektide kohta, kordub küsitlustele antud vastuste hulgas, nagu ka muid meetodeid viljelevates analüüsides (Telaar $2007^{6}, 18-19$, 83-84, vt ka joonis 32 ; Neustaedter, Tang, Judge 20107, 1778, 1780; Willis 2010 , 50-54;

${ }^{6}$ Küsitluse vastajaskonna moodustasid 1982 saksakeelsete maade geopeitjat.

${ }^{7} 185$ vastajast valdav osa olid USAst ja Kanadast.

${ }^{8}$ Katharine Willis, kes nähtavasti nagu minagi väärtustab geopeituse ühiselt täiendatavat andmekogu kui suurepärast uurimisallikat, võttis detailse vaatluse alla ühe aarde logid (kokku 74 külastuse raportid aastatest 2005-2010). 
Hawley 2010, 244). Geopeitjad oskavad sellist mänguvälise tegevuse suhtes täiendava info tarbimist väärtustada - see osutub koguni üheks motiveerivaks teguriks (Telaar 2007, 78, 94; Saarenpää $\left.2009^{9}, 16-17,24\right)$.

Kuna kirjeldan käesolevas töös elualasid, millega geopeitust on seostatud või mille raamides tõlgendatud, tuleks pildi terviklikkuse huvides tutvustada ka vaadet kriminoloogia alalt. Võrreldes analüütikutega sotsiaalteadustest, kultuurigeograafiast, informaatikast, meedia- ja kommunikatsiooniuuringutest arutleb Francis Hawley (2010) hälbiva käitumise joonte üle. Tema käsitlus on pühendatud agonistlikule, peresõbraliku hobi harrastamisega võrreldes sportlikumale geopeitusele ning seetõttu on tal suurema tähelepanu all sooritamise hasart, saavutusvajadus vahendeid valimata, närvikõdi, risk, kuid ka sõltuvus - seigad, mida kas üldse mitte või vaid möödaminnes avavad teised geopeituse vaatlejad. Hawley $(2010,227)$ reastab definitsioonis mitu kõnekat aspekti korraga: "Geopeitus on sport, hobi, ajaviide ning puhkamisviis, mis nõuab "peidikute" leidmiseks arvuti abil hangitavaid andmeid, kaarte ja GPS seadet" (tsitaadisisesed jutumärgid on autorilt). Nagu näha, jäävad aardeotsimine ja lõbusad mängud seekord tahaplaanile. Tegevuses võib aga ilmneda "ettekavatsetud pettuse ja kuritegelikku aktsiooni meenutava käitumise tunnuseid" (Hawley 2010, 225, 233-234). Seal, kus Kenton O'Hara märkab sõbralikku konkurentsi aarde esmaleidmise aule või suurimale leidude arvule (2008, 1179, 1182, 1186), avastab Francis Hawley, geopeituses insaider ja akadeemilises tegevuses kriminoloog, et üksteise mänguseisu teadmine põhjustab mõnikord pinget ja rivaliteeti (Hawley 2010, 230).

Huvipakkuv on tema arutlus omistatud hälbelisuse juhtumitest, st olukordadest, kus valvsad kaaskodanikud kategoriseerivad geopeitjaid kahtlaste tegude sooritajateks. Et minu käsitlus on siiani olnud näidetevaene, järgneb tõestisündinud lugu Pärnu linnast. Novembris 2012 jutustas [valap] ootamatust kohtumisest:

Seni veel avaldamata aarde [---] peitmise ajal tabas mind teolt registreerimata kasutaja Eesti Politsei. Keegi valvas linnakodanik oli teatanud, et ühel Pärnu sildadest kavatseb keskealine meesterahvas enesetappu. Ju mu käitumine jättis kõrvaltvaatajale sellise mulje. [---] Õnneks kaunis naispolitseinik ( $\mathrm{hmm}$, misajast politseis modellid töötavad?) oli geopeituse kui sellisega kursis. Ta oli isegi osalenud kunagi "Pärnu muuli" aarde (minul näiteks siiani leidmata) otsimis-

9256 vastajat Soomest. 
protsessis. Tunnistasin ausalt, et mul ei ole mingeid enesehävituslikke plaane. Lausa vastupidi. Kuna selle aarde leiulogide lugemine tulevikus mind eriti huvitab, siis pole lähitulevikus seda ka karta. Peale dokumentide kontrolli lahkusime sõpradena. Politsei keeldus logiraamatusse FTF jätmast. Nii et selle aarde otsimisel võite mööduvale sini-valgele autole lehvitada - need on sõbrad. Vat nii on lood siin Pärnus (vt Teolt tabatud).

Eesti geopeituse kontekstis tekitavad liialdused, ohuolukorrad, onnetused, seaduserikkumise juhtumid, kui neid tuleb ette kas kohalikus mängus või mujal maal, alati foorumivastukaja või märkusi otseselt aarete lehekülgedel ja mõnikord toovad kaasa mängureeglite täiendamise. Samuti kutsuvad postitajad kaaslasi üles säilitama tervet mõistust, mängu ilu ja vajadusel turvalisust.

Ärijuhtimise ja turunduse asjatundjad Heather Skinner, Gareth White ja David Sarpong aga klassifitseerivad geopeituse marketingiorganisatsiooni aastakoosoleku ettekandes, mille põhisisuks mobiilse tehnoloogia kasutamine turismis, sotsiaalseks praktikaks. 20. sajandi lõpu- ja 21. sajandi alguskümnendi praktikateooria ${ }^{10}$ tähttööde põhjal käsitlevad nad geopeitust kui kompleksset sotsiaalse tegevuse vormi, mille raames inimesed kokkulepitud reeglite toel teevad ühise teotsemissuuna heaks ühiseid jõupingutusi, kujundavad hüvesid (internal goods), mida ei saa muul moel, kui ainult selles praktikas osaledes (näiteks nii peitmiseks kui ka otsimiseks kulutatud energia, kogetud emotsioonid); valdavad spetsiifilisi oskusi ja oskusteavet ning tegelevad oma ürituse ajalooga (Sarpong, White, Skinner 2012, [2-3]). Olles ühtpidi vaadates sotsiaalne praktika, on geopeitus ka nende silmis ikka kõrgtehnoloogiline versioon peidetud varanduste otsimisest, sport ja ajaviide (samas, [1]).

Minu jaoks oli mõnevõrra üllatav, et Lynne McNeill, kes folkloristina valdab rahvaluule žanrisüsteemi, kuhu traditsiooniliselt paigutuvad mängud, väldib seeriaviisilist ühistegevust ja nö kaasaskantavaid kohti vaagivas huvitavas töös (McNeill 2007) geocachingu liigitamist mängude valda. Mõiste mäng neli kasutuskorda artiklis tulevad näitetekstidest. Rändavate aiapäkapikkude žanri (ja olemuse) määratlemisel on tema sõnul valida vembu (traditional

${ }^{10}$ Uuritavate nähtuste praktika mõiste kaudu tõlgendamise potentsiaalist folkloristikas annab hea ülevaate Simon Bronner. Praktikad, mille üle teoretiseerida, hõlmavad tegevusi ja väljendusviise (kombed, harjumused, rituaalid, kinnismõtted, õppimine, sooritused, sealhulgas folkloor), mida tajutakse korduvuse ja varieeruvuse tõttu omaseks saanud olevatena (Bronner 2012, eriti 31). 
prank), tänapäevamuistendi (contemporary legend), põrandaaluse tegevuse (underground movement) ja mängu ( $a$ game) vahel ( $\mathrm{McNeill}$ 2007, 289). Üldistavalt aga leiab ta, et "seeriaviisilise ühistegevuse kõik juhud hõlmavad esemeid ja protsessi, mis toob kaasa olukorra, et [vaadeldav] traditsioon jääb žanriliselt materiaalse kultuuri ja kombe vahealale, kui mitte mainida osaliste poolt kasutatavat ehk eemilist mängu-kategooriat" (samas, 288). Muidugi lähtub distantseerumine mängužanrist otsestest uurimisküsimustest: McNeill ei võtnud oma ülesandeks süveneda vaadeldavate tegevuste mängulistesse joontesse, vaid keskendus asjade edasiandmise või esemelt esemele liikumise kui kaasaegse kombe jälgimisele. Kas seda teha mängu eesmärgil või kuidas omandab tegevus mängulisi jooni, on tõepoolest juba eraldi küsimus.

Geopeituse mängulisus on seni viidatud käsitlustest kõige taotluslikumalt esil Lasse Gram-Hanseni töös, mis näitab, kuidas hobi innustab kaasa tegema neid, kellele selline tegevus avastuslikkuse ja tehnoloogia sümbioosis rõõmu pakub (persuasive perspective; Gram-Hansen 2009). Otsese praktilise eesmärgita tegevus köidab, me tahame mängida mänge, hoolimata sellest, et see ei vii mingi ilmse resultaadini, arutleb ta Johan Huizinga mõttekäigule viidates (samas, [6]; vt ka Huizinga 2003 [1938], 11). Huvitaval kombel kirjutab taani uurija geopeitjate motivatsiooni mitmekülgselt analüüsides samadest asjadest, mida Gill Clough esitleb informaalse õppe mõistetes. Gram-Hansen näeb ja näitab veenvat intentsiooni (persuasive intention) kohaliku ajaloo, geograafia ja folkloori tundmaõppimises, keskkonnahoiu-alase teadlikkuse kasvus, tervishoiuküsimuste, isegi poliitika ja äriprobleemide osalises integreerimises, isiklike kogemuste vahendamises - kõik elemendid mõjutavad-kujundavad hoiakuid, käitumist, isegi maailmavaadet (Gram-Hansen 2009, [6]). Niisiis - geopeituses kui mängus põimuvad meelelahutus ja õppimine.

\section{Mängu tunnused ja geopeitus}

Lasse Gram-Hanseni mängu mõistet toetav uurimus inspireerib selgitama harrastuse mänguolemust veelgi detailsemalt. Kuidas mahub geopeitus mängu žanriraami? Žanristamine pole eesmärk omaette, kuid ehk on avastuslikku väärtust tähelepanekutel, mille poolest sarnaneb geopeitus teistele mängudele, mille poolest mitte. 
Eespool toodud definitsioonid rõhutasid tehnoloogiakasutuse tõttu lisandunud uudsust. Kuid kas tehnoloogiline uudsus teisendab mängu olemust võrreldes klassikaliste sise- ja välimängudega? Kuidas mõista mängivat inimest ehk geopeitjat?

Selguse saamiseks vaatan lähemalt geopeituse toimumiskoha ja tavaelust eemaldumise probleemi, saladuslikkust, kaasahaaravust ja mänguri meeleseisundit, reegleid, mängimisvabadust, samuti vormuvaid vastandusi päriselt-mängult ning mängult-tõsiselt. Nüüdisaja kui info- ja digiajastu iseloomustuses on juba kõlama jäänud, et elame mängimise ajastul (Aarseth 2003, 1; Boellstorff 2008, 21; Rebane 2012). Uuteks märksõnadeks on performatiivsus, tegemine, kehalisus, praktikad, kogemus (Kaljundi 2011).

Johan Huizinga (2003 [1938], 18-19) tõi mängu formaalsete tunnuste hulgas esile ruumilise piiri:

Iga mäng toimub oma mänguruumis, mis kas materiaalselt või ainult ideaalselt, kavatsuslikult või endastmõistetavalt on juba ette tähistatud. Vormiliselt pole erinevust mängu ja püha talituse vahel, formaalselt ei saa püha paika eristada mänguruumist. Areen, mängulaud, nõiaring, tempel, teatrilava, filmilina, kohtusaal - vormilt ja funktsioonilt on nad kõik mänguruumid, st püha pind, eristatud, tarastatud, seal kehtivad erilised reeglid. Nad on ajutised maailmad tavalise maailma sees, milles aset leidev tegevus on eraldatud teistest. ${ }^{11}$

Käesoleva vaatluse kontekstis lähtub toodud tsitaadist otsekohe küsimus, kus on geopeituse tähistatud mänguruum. Kas aardelaekaid peites ja otsides ning kõigest internetilehekülgedel ülevaateid kirjutades luuakse tavalisse maailma ajutine maailm, kus toimub tavaoludest eraldatud tegevus? Arvutimängu maailma saamiseks tuleb käivitada arvuti ja vastav programm, et sinna siseneda, maailm ilmub ja kaob vastavalt seadme sisse-väljalülitamisele, kusjuures pärismaailmast ei saa välja logida, leiab Tom Boellstorff (2008, ${ }^{11}$ Tsitaati on mängu-uurimustes ikka ja jälle taasesitatud ja töödeldud. Katie Salen ja Eric Zimmermann (2004) laiendasid maagilise ringi tinglikult mängu toimumiskohtadele üldse. See tõi kaasa ebatäpsete hilisemate refereeringute tulva, nagu oleks Huizinga väitnud, et mäng toimub maagilises, tavamaailmast jäigalt eraldatud ringis. Huizinga raamatu pealiskaudse, et mitte öelda vigase lugemise toovad päevavalgele näiteks Montola, Stenros ja Waern (2009, 7-8) ning Cristopher Moore (2011, 373, 377). Viimane nimetab veel teoreetikuid, kes "Homo ludensi" suvalise tõlgendamisega kaasa polnud läinud. 
242-243). See osa geopeituse mänguruumist, mis asub online, on ligipääsetav samal moel nagu arvutimängud ja ükskõik missugune virtuaalmaailm. Geopeituse virtuaalne kodu on piiristatud unikaalse asukoha-aadressiga, virtuaalmaailma avaruses on markeeritud geopeituse territoorium. Harrastamiseks on vaja käia virtuaalmaailmas, kuid sama vajalik on külastada füüsilise maailma mänguliselt tähistatud paiku. Aarete leheküljed on nagu peidikute virtuaalsed esindused või saatkonnad Interneti virtuaalriigis.

Füüsilises maailmas asuvate peidikute ja muude pärismaailmas toimuvate mängude kohaaspekti üheks erinevuseks on see, et üldjuhul korjatakse rekvisiidid kokku, kui mänguetapp läbi. Kummikeksu kumm viiakse tuppa, malendid pannakse karpi, kekskasti jooned peseb vihm, liivalossid uhub laine, nukud lähevad mänguasjakasti (tõsi, siin on valikuid: jäävad nukumajja otsekui edasi elama), teatris tõmmatakse eesriie ette, kontserdisaalis pannakse klaverile kaas peale, mask võetakse maha, staadioni värav keeratakse lukku näiteid võib tuua lõputult. Geopeituse aardekarpe võib otsida millal tahes, sest mänguruum on kogu aeg sisustatud, õigemini - see ei erine mitte-mänguruumist. Mängukohad moodustavad mitte-mängu ruumis permanentse kihi, mis meenutab digikaardi spetsiifilist andmeladestust, millega on rikastatud aluskaarti, ainult et geopeituse puhul on "aluskaardiks" pärismaastik. Kogu aeg olemas olemise poolest sarnanevad geopeidikud ei millegi muu kui päris peitvarandustega. Need lebavad samuti oma peidikutes. Jällegi võib loetleda terve rea erinevusi, mille poolest geopeituse aarded - oma füüsilisuses sama päris kui rahapajad (olles mängult aarded pigem mänguväliselt), erinevad siiski viimastest (näiteks materiaalse väärtuse ja peitmise eesmärkide poolest, samuti võetakse rahapada avastamise korral välja, geopeituse aare aga pannakse tagasi). Geoaarete puhul on kokku lepitud, et laekaga tohivad manipuleerida paljud asjaosalised (ka informatsioon on jagatav), pärisaarete puhul on see väga piiratud (samuti teadmine peidikust).

Seniöeldu põhjal ei tuleks arvata, nagu polekski geopeitus mäng, mis sest, et ajutine maailm osutub sellekssamaks ajaliseks maailmaks, milles me elame, ja mängu ruum kujutab endast täiendavalt kujundatud punkte pärismaailmas koos nende virtuaalsete saatkondade ja osalejate virtuaalse suhtlusruumiga.

Kohatähistuse poolest on geopeitus niisiis isemoodi mäng, mis seob sooritused ja asetused füüsilises maailmas täiendavate virtuaalsete üksikasjadega, sealhulgas neisse puutuvate lugudega. 
Mingis mõttes on olukord vastupidine sellele, kuidas Epp Annus (2002, 99) kirjeldab mängimist, mis kasutab tugesid füüsilises maailmas: toolid on rongivagunid jne. Geopeituses on füüsilistel aaretel "toed" virtuaalsete sissekannete ehk logide vormis hoopis virtuaalsel platvormil.

Seni keskendusin geopeituse kui mängu toimumise ruumile, et jälgida, kuidas realiseerub mängule tunnuslik vajadus eraldatud ala järele. Kuid kas ja mil määral eemaldub harrastus tavalisest elust? Selgitan küsimust taas mängudefinitsioonide abil. Kuna geopeitus toimub füüsilises maailmas, kuid kasutab ka virtuaalset platvormi, pean olema kursis, kuidas on iseloomustatud eraldumise teemat virtuaalsete keskkondade näitel. Klassikalise ludoloogia seisukohalt "pole mäng tavaline või tegelik elu, vaid sellest välja astumine ajutise aktiivsuse sfääri, millel on oma teotsemissuund" (Huizinga 2003, 17). Roger Abrahams nimetab mänge teiste tegevusžanride hulgas, mille kõigi ühiseks omaduseks on olla ühekorraga tegelik ja mittetegelik (unreal yet more real at the same time), st küsimus on tavalisega võrreldes rohkem rõhutatud, eneseteadlikus ja stiliseeritud käitumises, mis on ühtlasi päriselt, sest selle raames rakenduvad igapäevased motiivid ja stseenid, mis asetatakse uude perspektiivi (Abrahams 1977, 80-81, 84). Põhimõtteliselt erineb Richard Schechneri lähenemisviis: "Oleks vale arvata, et mängimine on tavalise elu katkestus, pigem on tegu kogemuse kontiinumiga" (1993, 42).

Tom Boellstorff aga, jättes kõrvale žanriteooria, arutleb kujuteldava ja tegeliku vahekorra üle, võimaluste üle mittetegelikku teoks teha, virtuaalsuse mõiste kaudu selle sõna laiemas tähenduses. Vaatluse all on viisid kujutlusmaailma tajumiseks, näiteks unistuste ja unenägude, mängu, ilukirjanduse, rituaalide, teatri jne vormis, kusjuures keel on samuti virtuaalsuse loomise ja juurdepääsu vahend (Boellstorff 2008, 33). Nii nagu kunagi kirjutama hakkamine (ja film aegu hiljem) lubas virtuaalseid maailmu uudselt võimalikuks teha, on 21. sajandi tehnoloogiad toonud kaasa veel avaramad võimalused, mis lasevad manipuleerida virtuaalmaailma esemete ja olenditega, samuti sünkroonselt suhelda omataoliste pärismaailma inimeste ja nende avataridega (samas, 34-38, 45-46; vt ka Frasca 2003, 233). Virtuaalmaailmas askeldamine on üha enam tavalise elu osa. Seetõttu tekitab tavalisest elust erinev aktiivsus arvutimängude teoreetikutes hämmastust ja vajadust seda tunnust infotehnoloogia valdavaks saamise tingimustes ümber vaadata (vrd Malaby 2007, eriti 96-97; Moore 2011, 378-379). Jesper Juul (2005) näiteks tõlgendab arvutimängimist pool-tegelikkuse (half real) 
mõiste abil. Videomängu mängija järgib tegelikke reegleid, võidab ja kaotab ning tunneb päriselt kaotusekibedust ja võidurõõmu, kuid opereerib üksustega kujutluslikus, fiktiivses maailmas. Paadunud mänguri (hardcore gamer) seisukohalt on videomängu mängimine tõepoolest tema tavalise elu osa, mitte stiliseeritud käitumine ülevas meeleolus.

Kõikjalolevate mängude omapära saavutatakse aga just nimelt tavaelu ja mängu vahelise mõttelise piiri ähmaseks tegemise teel; mäng tungib tavaellu, tavaelu tungib mängu, kinnitavad Jaakko Stenros, Annika Waern ja Markus Montola (2012, 341). Selle tulemusel omandab kaasategija mängija vaate maailmale, kõike ümbruskonnas nähakse otsekui läbi mänguprisma, mänguetappi läbides kogetav on ühtaegu mängukogemus ja elu-kogemus, improviseerimine kontekstuaalsete kokkusattumuste (samas) tõttu tekkivate väljakutsete lahendamiseks. Tõele au andes tuleb märkida, et Roger Abrahams tõi samu omadusi esile esitus- ja tegevusžanride näitel üldisemalt, mis pisut kahandab igapäevaelu ja kõikjaloleva mängu vastastikuse põimumise avastuslikkust (üheks Abrahamsi näiteks oli tegeliku elu juhtumi kommenteerimine mõnes filmis nähtu abil; Abrahams 1977, 84-85). Muidugi, kõikjalolevas mängus lähenevad elu ja mäng kergemini soorituslikkuse, kehalisuse tõttu: mängija proovib ja kogeb kõike omal nahal. Tavaelu ja geopeituse kokkupuuted ja -põrked äratavad osalistes nii palju tähelepanu, et neist jutustatakse lugusid.

Tavalisest esile küündiva, erilise aktiivsuse kriteeriumil siiski on geopeituse tõlgendamisel mõtet, eriti kui pidada silmas ka osaleja teadlikkust ja kavatsuslikkust, mängija meeleseisundi ("geopeituse tuju", geocaching mood) saavutamist. Hobi harrastamist saab tõlgendada kui eluliste seikade - antud juhul siis aarde varjulepaneku ja hilisema ülesotsimise - teise perspektiivi asetamist (vrd Abrahams 1977,80 ) ehk mängu žanriraamis, kuid samal ajal on geopeidikute otsimine sõna otseses mõttes tegelikult ka otsimine, mitte selle teesklemine või jäljendamine. Muu elu ja geopeitus langevad kokku, põrkuvad ja vahelduvad, kuna otsimiskäigud toimuvad tavaliste soorituste vahel või neid ühendades. Online logid geopeitus.ee-s pakuvad kirkaid näiteid, kuidas hobi lõikub argitoimetustesse. Vandi aarde otsija jutustab otsingust juulis 2009:

Panin kartulid potis keema ja lülitasin arvuti käima. Mida, keegi on Tartusse aarde pannud? Et kinnitada legendi, et kui keegi Tartusse aarde paneb, siis on esimeseks leidjaks kas Aints või Lassie, asusin 
teele. Kohapeal vehkles mingi mugu, mõtles, et pü̈ab kala. Mina nii ei mõelnud ja peagi ta lahkus parematele kalapüügikohtadele. Eilsest sillaavamise peost oli sillale jäänud veel igasuguseid pudinaid. Ja ükshaaval käivad linnaelanikud uut silda uudistamas / pildistamas veel nii paar kuud. Jõudsin koju tagasi, kartulid olid pehmeks keenud. Mõnus hommikune FTF oli. (vt Vandi 2009.)

Mis puutub töö ja aareteotsimise vahekorda, siis selles osas tuleb üht-teist päevavalgele kogukonnauurimustes. Saksakeelsete maade geopeiturid näiteks võtavad ette nädalavahetuse turneesid ja sisustavad osa puhkust hobiga (Telaar 2007, 63-64, 80), mis viitab eristuvaks aktiivsuseks pidamisele, seda ka "tavalise" puhkuseveetmise taustal. Online-etapid see-eest liituvad mitmekülgse arvutikasutaja käitumisharjumustega internetis. Peale selle tehakse virtuaalne informatsioon vajadusel maastikul kasutatavaks - aardekohta näitab satelliidilt tulev nool navigeerimisseadme ekraanil ning mobiilne arvutiside võimaldab lisavihjete taipamiseks üle lugeda eelmiste otsijate logisid. Kuna arvestatav hulk harrastajaid on hõivatud infotehnoloogia alal laias tähenduses, tekivad võimalused (ja ahvatlused, vt Hawley 2010, 235) elukutse ja geopeituse paindlikuks ühendamiseks. Soodustavaks teguriks on inimeste töine mobiilsus ning töö iseloom: ametiasjus liikvel olles mahutatakse oma käikude hulka ka mõne aarde otsimine (Telaar 2007, 64; Hawley 2010, 231; osaleja sõnu refereerivalt nt Klaus 2010). "Tõsiste" tegude ja mängu paindlikku vaheldust lubavad teiselt poolt asjaolud, mille tõttu osalejad on vaba(ma)d oma aega struktureerima (haruharva on selleks töötus ${ }^{12}$; Telaar 2007, 106, tabel 13).

Mängu erilisusega seostub Huizinga kultuurikirjelduse kohaselt salapära, mis mängu ümbritseb (2003 [1938], 22). Tema sõnul kasvatab saladuseks tegemine omalt poolt mängu võlu. Saladus on teguriks geopeituses ja harrastuse ümber, ja see tuleneb tegevuse mänguolemusest. Iseenesest ei ole tegu salaseltsiga, kuhu ebatavaliste rituaalidega võetakse vastu kutsutud ja kontrollitud liikmeid, lausa vastupidi. Mängimiseks vajalik informatsioon internetis

12 Sellel taustal, et geopeitjad on suures osas täistööajaga hõivatud või omandavad haridust info- ja kommunikatsiooni valdkonnas, mõjub dissonantsina autsaiderist netikommentaatori väide Pärnu Postimehes 14. II 2010 ilmunud loo "Geopeitus võimaldab aardeid leida igast Eesti nurgast" (Klaus 2010) järel. Sõnavõtja oletas, et inimestel on töötutena igav ja pole muud teha kui laste kombel peitust mängida (kommentaar ei ole enam online-väljaandes leitav). Tegu on ühe näitega väljaspoolsest inkrimineerivast tõlgendusviisist. 


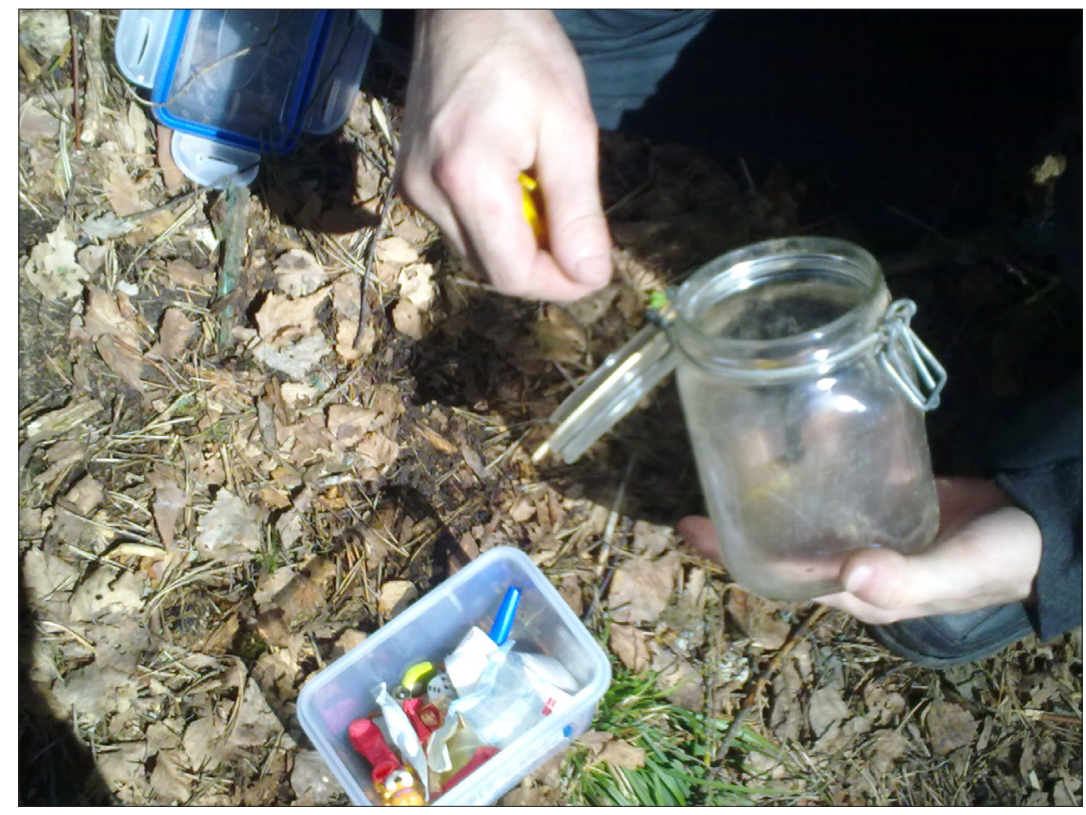

Foto 3. Aarde omanik peidikut hooldamas: vana konteineri väljavahetamine. Mare Kalda foto 2011.

on vabalt leitav ja kasutatav isegi registreerimata kasutajatele (geocaching.com andmekogusse siiski igaüks ei pääse), ja nagu eespool esile tõin, eristuvad geopeituse sooritused tavalisest elust mõõdukalt, ilma et eeldataks ümberkehastumist, maskeerimist, kellegi/millegi jäljendamist vms. Näen siin mõistatuslikkust kahes tähenduses. Ühelt poolt on tegu mängusisese saladusega - peidetud asjadekastikestega, millest igaüks muutub konkreetsele osalejale avastatud saladuseks niipea, kui see õnnestub üles leida. Teiselt poolt on saladuse teadmine mängiva kogukonna ja mittemängivate mugude (vt Sõnastik) eristaja. Informaatik Risto Sarvas, üks esimesi geopeituse analüüsijaid, rõhutab oma vestluskaaslaste sõnade toel ühise saladuse tunnet - aarded peituvad kõigil otsekui nina all, kuid need, kes saladust teavad, kuuluvad geopeitjate hulka (2002, 10; sarnaseid mõtteid vt ka Neustaedter, Tang, Judge 2010, 1758). Saladuse teemat kajastavad mitmest küljest online logid ja fooru- 
mipostitused - jutustatakse näitelugusid, kuidas aarde leidmine on nõudnud kelleltki jõupingutusi, samuti sellest, kas peidiku saladust on või ei ole õnnestunud hoida kaasinimeste mitteasjakohase tähelepanu eest (probleemiks rahvarohketest kohtadest otsimisel, eelkõige linna-aarete puhul). Sellistes olukordades toimub otsekui mäng mängus: geopeitja teeb, nagu polekski tal plaanis pargipingi alt aardekonteinerit napsata. Soov aaret mitte reeta osutub nii mõnigi kord leidmata jäämise põhjuseks. Mitut liiki saladusehoidmise logisid on ajendanud Üllatuse aare. Kahesajast logist 20s mainitakse mugusid, kellest sõltus, kui aeganõudvaks otsing kujunes. [silja] sissekanne juulis 2012 vahendab olukorraga toimetulekut ja ühtlasi näitlikustab geopeitjate ja mugude ühte suhtlusvõimalust:

Samal tänaval elav mugu tuli küsima, mis asju siin puu all pidevalt aetakse. Kuna vihma sadas, olime meie loomulikult vihmavarjus ja näitasime lastele, kuhu päkapikud suvel peitu saavad minna. (vt Üllatus.)

Osa aaretest siiski kaob, osa leitakse rüüstatuna - mõnel juhul mängivad kogukonnavälised leidjad destruktiivset vastumängu. Ühte mängu algusajastul peidetud aardesse oli pandud ka tollal reaalselt kehtinud raha. Aarde leidjad avastasid paberkandjal logiraamatust geopeitusevälise sissekande sooviga, et pandaks edaspidi veel ja rohkem. Kuid juhuleidjatelt on ka geopeituse vaimus sissekandeid, millest kas järgmised geopeitjatest leidjad või aarde omanik (vt Sõnastik) online logis samuti kaaslasi informeerivad (nt [gpsitu] vahendab oma leiuteates augustis 2007 "Militaarse Hiiumaa" juhuslike leidjate sõnumi). Sellised kirjeldused näitavad, kuidas lisandub saladusest teadjaid, nagu ka neil juhtudel, mil geopeitjad selgitavad oma tegutsemise asjaolusid juhuslikele pealtnägijatele.

Francis Hawley käsitlus, kus ta võrdleb geopeitust spiooni-, sõjamängu ja orienteerumise kombinatsiooniga, on omamoodi inspireeriv. Aarde peitmine, peidiku asukoha määramine ning lõpuks aardekarbi tagasipanek pärast selle sisu uurimist ja logimist nõuab paljudel juhtudel vargsi tegutsemist, mis tekitab närvikõdi ja kordamineku korral isikliku triumfi tunnet (Hawley 2010, 231, 235, 237).

Johan Huizinga kirjutas mängu kui "absoluutselt primaarse elukategooria" tunnuseid iseloomustades hullutamisvõimest, mis seostub mängust saadava lõbuga (2004 [1938], 11). Küsimused kaasategemise sügavusest, isegi sulandumisest mängu, aga sellega seoses ka eskapismist, sõltuvusest, mänguri meeleseisundist olid 
kõik tema tähelepanu fookuses juba 20. sajandi alguskümnendite kontekstis. Nüüdisludoloogias jätkub samade probleemide valgustamine eelkõige seoses arvutimängudega ning valdavalt osalevate uurijate endi poolt (Montola 2012, 313). Samuti kogub kultuuriuurijategi seas hoogu reageerimine mänguliste tegevuste esilekerkimisele paljudel elualadel, näiteks hariduse omandamises, organisatsioonikultuuris, turunduses. Seda, et mäng pole tingimata lõbus ega lõbu tekitav, on rõhutanud eelkõige uurijad, kes vaatlevad võrdlevalt mitut kaasategemisžanrit üheskoos (mängu tumedast poolest eriti Schechner 1993, 21-27). Videomängude uurimustest selgub, et mängijat valdab lai galerii mitmesuguseid emotsioone virtuaalmaailma otsimiskäikude sooritamisel. Geopeituse puhul on mängijahoiak argumendiks, kõikjalolevas mängus peituv kahetisus erutab meeli. Nagu kinnitavad logid ja kogukonnauurimuste tulemused, peetakse osalemist toredaks, rõõmu ja rahuldust pakkuvaks. Eesti foorumis arutleti alates jaanuarist 2011 seoses harrastuse kümnenda aastapäevaga teemal, miks keegi hobiga tegeleb, mis mängu juures kõige rohkem meeldib. Üheksateistkümnes postituses korduvad väljendid, mis kinnitavad, et kaasategemine on tore, rõõmu pakuvad otsimine, leidmine, samuti eneseületamine. Kogenud geopeitja [trine] kirjutab pikemas tagasivaates muuhulgas:

\footnotetext{
[---] K. lahkes ja lõbusas autos sai geopeitus uued mõõtmed - kui mina olin linnast väljas olevaid aardeid alati otsinud muu tegevuse kõrvalt, näiteks teel orienteeruma, siis siin nägin geopeitust kui eluviisi: sõidetaksegi nädalavahetuseks pere ja sõpradega aarderetkele. Tundus tore ja tundub siiani! Loodetavasti paistab eelnenust, kui imeliselt see kõik mu senised huvid ühendab ja veel nii palju rohkem juurde lisab. (vt 10 aastat.)
}

Seega on mängu lõbu geopeituses aktuaalseks teguriks ja kuulub osalejate motivatsiooni hulka (Sarvas 2002; Saarenpää 2009, 16-17, 21; Gram-Hansen 2009, [6-7]; Ihamäki 2012, 135). Francis Hawley, seespoolne analüütik, tungib oma essee järeldustes lausa alusmehhanismideni. Hawley mõttekäik selgitab muuhulgas erinevate küsitluste sarnast tulemust: protsentuaalset meeste ülekaalu kaasahaaratute hulgas (vt tabel 1). Tema sõnul lubab geopeitus ületada argitegelikkust ja rahuldab (eelkõige selle sportlikus kehastuses) meesmängijate fantaasia teatud aspekte - mängus ei ole relvad ja naised, elu ja surm, vaid tegu on mõnevõrra kõrvalekaldelise, aga siiski legaalse otsimistegevusega, millesse kuulub parajas annuses riski, aardejahti, põgenemist ja pidulikkust (Hawley 2010, 249). 
Naissoost osalejate tegutsemisajendid jäävad niisuguses tõlgenduses mõistatuseks.

Tabel 1. Geopeitjate sooline koosseis.

\begin{tabular}{|l|l|l|l|}
\hline Uurimus või allikas & Vastajaid & Naisgeopeitjate \% & Meesgeopeitjate \% \\
\hline Telaar 2007 & 1982 & 20,23 & 79,77 \\
\hline Saarenpää 2009 & 256 & 33 & 67 \\
\hline Clough 2009 & 659 & 30 & 70 \\
\hline $\begin{array}{l}\text { Neustaedter, Tang, } \\
\text { Judge 2010 }\end{array}$ & 185 & 26,3 & 73,7 \\
\hline geopeitus.ee & $675^{13}$ & 33,18 & 66,82 \\
\hline
\end{tabular}

Lisaks toimumisruumile, muust aktiivsusest eraldumisele, saladuslikkusele ja kaasahaaratud inimeste mõjutamisele, väärivad märkimist mängu reeglid ja korrastatus. Huizinga järgi valitseb mänguruumis (mis geopeituses laotub tavamaailma) "omaenda tingimatu kord, [---] mäng loob korda; [---] tung luua korrastatud vormi läbib igasugust mängu" (Huizinga 2003 [1938], 19). Ühelt poolt väljendub see reeglite kaudu ja mõjutab otseselt kehalist tegevust, kuna reeglid struktureerivad mängu raames tehtavaid toiminguid. Teiselt poolt ilmutab parimat korrastatust mängu virtuaalne kodu geopeituse kestmiseks vajalike andmete struktureeritud jaotusega. Keskkond geopeitus.ee näeb välja nagu hästisisustatud töökabinet otstarbekate ühenduskoridoridega, kus kõik vajalik on käepärast võtta ja mis erinevalt päris-ametiruumist ei lähe kunagi segamini ega kattu tolmuga. Ühisele platvormile andmete lisamine on iseenesest üks mänguetappidest, mida juhivad kogukonna liikmete kujundatud, foorumidiskussioonis välja töötatud reeglid. Seega puudutavad reeglid ühtaegu virtuaalse kodu sisustamist, aga korrastavad ka peitmis- ja otsimisretkedel käimist. Lasse Gram-Hanseni sõnul peavad geopeituse reeglid tagama, et hobi püsiks terve ja areneks edasi ning et inimesed ei peaks kogema ebameeldivusi $(2009,4)$.

Lisaks otseselt mängu puutuvatele käitumisjuhistele tõmmatakse mängu laiemalt kehtivaid kirjutatud ja kirjutamata seadusi ja probleeme (näiteks loodushoiu nõuete järgimine, omandipiiride austamine, pommipaanika vältimine). Reeglid, mis aitavad korras-

${ }^{13}$ Geopeitus.ee-s registreeritud kasutajate andmete põhjal. Arvesse on võetud vähemalt kümne leiuga osalejad. 
tatust saavutada ja geopeitust sellisena hoida, on sõnastatud mängu kestmise jooksul, kuid aegajalt puhkeb foorumis diskussioon mõne reguleerimist vajava detaili üle uuesti. Ülekordamist on vajanud, et aare tuleb peidikusse tagasi panna nii, nagu oli see enne leidmist, et pole mõtet mõelda välja seiklusi ja leidmisi ning et ei sobi sõimata uusi liitujaid apsude eest jne (vt Mängureeglid).

Roger Abrahams, kes, nagu ülalpool osutatud, pooldab mängu igapäevast eemaldumise põhimõtet, näitab seda realiseerumas kahel viisil - üks on asjaliku igapäevakäitumise stilisatsiooni, teine aga mängulise ümberpööramise vormis (Abrahams 1977, 90). Kumbki tunnus ei taha geopeituse puhul hästi paika pidada. Järjekindla tõlgendusega võib ehk mängimise eesmärgil, vahva-olemise pärast peitmises-otsimises näha väärtuslike esemete hädavajaduse sunnil peitmise ja hilisema avastamise stilisatsiooni. Samasugust tõlgenduslikku uperpalli võimaldaks inversiooni võte: aarde varjulhoidmise idee on mängu teenistusse asetamisega pea peale pööratud. Instrumentaalses mõttes aga on geopeituse aarded ja tegelikud aarded ühtviisi päriselt, ühtviisi peidus, eeldavad asukoha teadmist ja leidmistingimuste tundmist. Francis Hawley $(2010,249)$ arutluskäik viitab võimalusele, et mängijate eduelamused otsekui kordaksid modernsete filmikangelaste James Bondi ja Indiana Jonesi kogemusi. ${ }^{14}$ Nii või teisiti, kõnealune tegevus ei ilmuta korda mitte ainult informatsiooniplatvormi kaudu, mänguetappide järgnevus tekitab soorituste rütmi ja seda nii individuaalse(te) mängija(te) kui kogu harrastajaskonna tasandil. Natuke teise rõhuasetusega käsitleb asjade ringlemist ja inimeste käimist objektilt objektile Lynne $\mathrm{McNeill,} \mathrm{kes} \mathrm{liigitab} \mathrm{geopeituse} \mathrm{aarded} \mathrm{sellist} \mathrm{tüüpi} \mathrm{seeriaviisilise}$ koostöö objektideks, mille puhul asjad on paigal, inimesed liiguvad ja panustavad paigalolevasse objekti ühekaupa (McNeill 2007, 288). Sama kordub tegelikult online: aarde kodulehekülg on "paigal", leidjad teevad sinna külastamise järjekorras sissekandeid. Aarde

${ }^{14}$ Sellel taustal on kõnekas Indiana Jonesi esitlemine aardeküti koondkujuna. Näiteks arheoloog Valter Lang, kes 2005. aastal eksperdina vaagis muinsuskaitsjate ja isehakanud arheoloogide vastuseisu, väljendas kahetsust, et meedia kaldub viitama heausksetele Indiana Jonesitele, aga kurjale muinsuskaitsele (Lang 2005). Erinevaid geopeitjate tüüpe uurinud insaiderist psühholoog Siru Saarenpää kasutab koondportreede väljajoonistamiseks samuti populaarkultuuri tegelasi, kuigi James Bondi, Indiana Jonesi, Sherlock Holmesi jt kõrval seisavad ka sellised traditsioonilised kangelased nagu kuningas Artur, võlur Merlin ja Robin Hood (Saarenpää 2009). 
virtuaalses kodus viibida saavad kasvõi kõik harrastajad korraga. Kuni mäng kestab, on keegi kogu aeg liikvel - kes infokeskkonnas uusi aardeotsimisi ette valmistamas, kes aaret peitmas, kes mitme aarde otsimisturneel, kes oma kogemusi logimas.

\section{Üksi ja üheskoos}

Täisvereline geopeitjaelu eeldab tegutsemist maastikul, st pärismaailmas. Seetõttu oleks problemaatiline pidada harrastajaid internetikogukonnaks, kuigi omavahelise suhtluse iseloom seda lubaks: mängu kulgu ja arendamist puudutava info vahetus toimub valdavalt - et mitte ütelda sajaprotsendiliselt - virtuaalselt. Huvitaval kombel inimestevahelised kontaktid ikkagi tekivad. Silmast silma suhtlus on soositud, kuigi geopeitusega on võimalik tegelda igaühel omaette. Sissekannete tegemine aarete virtuaalsesse kodusse on ka suhtlemine, kuigi vahendatud viisil. Võimalus teha geopeitust üksi eristab Daniel Telaari sõnul hobi teistest maastikumängudest, mis eeldavad mitut osavõtjat või koguni osavõtjate rühma, näiteks paintball, rebasejaht, varas ja võmm (Räuber und Gendarm), lipuvallutamine (Telaar 2007, 17), kus osapoolte tegevused on sünkroonsed. Geopeituse puhul muidugi sõltub iga üksiktegija tegevus samuti teistest, sest kaaslased hoolitsevad, et ühise ürituse kestmiseks jätkuks aardeid, mida otsida, ning et need oleksid heas korras nii oma füüsilises peidikus kui ka infokeskkonnas. Pole haruldane mitme geopeitja või geopeitjate rühma juhuslik põrkumine otsimise ajal, eriti linna-aarete puhul. Juhuslikult kohtudes kas saadakse tuttavaks või siis vahetatakse paar sõna inimestega, keda seni tunti kasutajanime järgi ja kelle olemasolust teati üksnes virtuaalsete logide põhjal. Eestis on niisugune võimalus alates 2005. aastast peale integreeritud mängu kui aardetüüp "Teolt tabatud" (vt Teolt tabatud), mis oma spontaansuses tekitab omakorda elevust. Sündmust jäävad kajastama lühikesed jutud, mida sageli illustreerivad pildid. 
Aktiivsemad geopeitjad on altid looma harrastusel põhinevaid uusi suhteid. Tekkivaid sidemeid väärtustatakse kõrgelt, nagu Eesti oludes kinnitavad teemakohased foorumisissekanded. ${ }^{15}$

Harrastusse on sisse kirjutatud ühiskogunemised ehk nn sündmusaarded (rahvusvahelises mängus event cache), mis on jooksvalt linkidena leitavad koduleheküljel geocaching.com. Liituda võib olenemata potentsiaalse osavõtja koduregioonist. Näiteks geocachingu 2013. aasta veebruarikuu kalendris oli iga päev vähemalt viis sündmusaaret. Laupäeviti olnuks geopeitjal võimalik valida umbes 40 event cache'i vahel maailma eri paigus (USA osariigid ja Kanada provintsid on nimetatud eraldi). Eesti geopeituses toimuvad ühiskogunemised alates 2004. aastast. Sündmuste kalender on sestsaadik üha tihenenud viielt kokkusaamiselt aastas enneolematult aktiivse 2012. aastani (lausa 15 sündmusaaret). Saksakeelsete maade geopeitjatest olid 1982 küsitlusele vastajast pooled osalenud vähemalt ühel sündmusaardel (Telaar 2007, 73). Üldise tendentsina selgub, et sündmusaaretest võtavad osa eelkõige pühendunumad tegijad, kellel on suhteliselt suur leitud aarete arv (samas, 77, 81).

20. sajandi lõpukümnenditel anti virtuaalsetele keskkondadele pessimistlikke hinnanguid, nagu kaotaks need inimliku läbikäimise sootuks (vt nt Putnam 2000). Kahtlused on hajunud kõikjalolevate mängude osas (Montola, Stenros, Waern 2009, 14-16, 126-128). Kuid ka arvutimängud ei tähenda kaugeltki mitte üksi ekraani ees istumist. MMOG-mängude ${ }^{16}$ analüütikud täheldavad, et aktsiooniga sünkroonselt käib suhtlusaknas vilgas vestlus, mängu sotsiaalne ja formaalne külg lõikuvad, ühine tegevus loob aluse mängu mõjutavale suhtlusele (ühe fantaasiamaailma, EverQuesti näitel Taylor 2006, eriti 9-10, 30-31). Enamgi veel, inimlike kontaktide huvilised korraldavad offline kokkutulekuid, mis võivad olla organiseeritud mängu tootjafirma poolt, kuid toimub ka mitteformaalseid kohtumisi. Samamoodi on avatud suhtlusaknad Second Life'i virtuaalmaailmas, kus erinevalt strateegiamängudest on

${ }^{15} \mathrm{Vt}$ nt [pekadripi] sõnavõttu foorumis (jaanuaris 2011), mis oli pühendatud kümne aasta täitumisele Eesti geopeituses: "Geopeitus on toonud kaasa suure hulga toredaid tuttavaid-sõpru..." ja [caro] sealsamas: "Mille üle mul eriliselt hea meel on, on need mu head sõbrad ja mõttekaaslased, keda ma siit mängust olen leidnud. :)" Peaaegu vormellikult analoogilised mõtted ka Ihamäki 2012, 146.

${ }^{16}$ Massively multiplayer online games (Ulatuslikud mitme mängijaga online-mängud). 
rohkem võimalusi ja tahtmist kirjutada elust üldse nagu ka elust väljaspool SLi (Boellstorff 2008, 198-199). Kuigi offline kokkutulekuid on peetud, jäävad aktuaalsed ulatuslikumad kontaktid selle keskkonna kasutajate vahel pigem hõredaks (Boellstorff 2008, 200), reaalset sõprust ja armastust individuaalsel tasandil muidugi tuleb ette. Tom Boellstorffi hinnangul on Second Life'i asukatel ilmne soov hoida virtuaalmaailma ja pärismaailma elu lahus, ei taheta purustada virtuaalmaailmas loodud illusioone (samas, 200-201). Geopeitjad seevastu on huvitatud kokkusaamisest pärismaailmas nende inimestega, kelle olemasolust hobi virtuaalses keskuses viibimise kaudu juba ammu teatakse. Geopeituse sündmusaarded kokkutulekud ühise, tavalisest võistluslikuma aardeotsimisega või mõne pidupäeva tähistamiseks on küllaltki levinud (vt ka Ihamäki 2012, 146-147). Lisaks otseselt harrastuse etappidesse puutuvatele seikadele pole Eesti geopeituse foorumis haruldane, kui pööratakse tunnustavat ja empaatilist tähelepanu kaaslaste isiklikele sündmustele ${ }^{17}$ ja saavutustele.

\section{Kokkuvõtteks}

Geopeituse mänguruum laotub laiali maailma, kus valitud punktid on eriliselt tähistatud: neis peituvad reaalsed aarded, virtuaalsete esindustega virtuaalses maailmas. Osalejad teevad geopeitust oma tavalisest elust vähe või suhteliselt vähe eristudes, mänguetapid paigutuvad mittemängu toimetuste vahele, kuigi neid võib sooritada ka tsükliliste geopeituse turneedena. Mängu raam, mis tekitab tunde muust tegevusest eenduvast aktiivsusest, on siiski tuletatav - seda markeerib vahetu otsimiskäigu ettevalmistus virtuaalse platvormi abil (andmete allalaadimine, asukoha koordinaatide väljaselgitamine, mõistatuste lahendamine) ja sellele osutavad füüsilises maailmas geopeituse eesmärgil tehtud teod. Osalejad annavad endale aru, et nad tegelevad teadlikult ja vabatahtlikult asjaga, mis kulgeb iseendas ja mida tehakse, sest see pakub lõbu. Niivõrd kuivõrd küsimus on toimuva tajumises, samuti enese tunnetamises sündmustes osaleja, isegi mõjutajana, jääb alati tõlgendusvõimalus, millele osutab Roger Abrahams. Tema sõnul me teadvustame, et

${ }^{17}$ Minu foorumikogemuse põhjal on kogukonda informeeritud vähemalt ühe geopere loomisest, mille puhul asjaosalised olid "gepsud ühte kappi pannud”, nagu üks õnnitleja väljendas. Geps on slängisõna GPSi - positsioneerimisseadme kohta. 
teeme kaasa rituaalide, näitlemise ja mängu tunnuseid ilmutavates sündmustes, ilma et nimetaksime iga konkreetset juhtu tingimata esinemiseks, mänguks või pidustuseks (Abrahams 1977, 108). Samas võib geopeitust pidada omamoodi mängude mänguks, kuna selle raames kehastuvad mitmed mängu kui žanri tahud - nii soorituslikud kui representatsioonilised elemendid. Geopeitus võimaldab võistelda ja konkureerida, kuid ka rahulikus rütmis kulgeda, väljakutset pakuvad sõnamängud, ülesanded ja mõistatused, osalejad omandavad kehalisi kogemusi ning jutustavad oma lugusid, on võimalik valida sooritus turvatsoonides, kuid soovi korral võtta riske, minna hasarti ja tunda närvikõdi - rikastada maailmas olemist geopeituse läbi.

\section{Kirjandus}

Aarseth, Espen 2003. Playing research: Methodological approaches to game analysis. Paper presented at the 5th Digital Arts \& Culture Conference, Melbourne, Australia (http://www.cs.uu.nl/docs/vakken/ vw/literature/02.GameApproaches2.pdf - 14.05.2013).

Abrahams, Roger 1977. Toward an Enactment-Centered Theory of Folklore. - Bascom, William (toim). Frontiers of Folklore. Boulder: Westview Press, 79-120.

Anderson, Leon 2006. Analytic Autoethnography. - Journal of Contemporary Ethnography 35, 4, 373-395 (http://dx.doi. org/10.1177/0891241605280449).

Annus, Epp 2002. Kuidas kirjutada aega. Tallinn: Underi ja Tuglase Kirjanduskeskus.

Bimber, Oliver; Raskar, Ramesh 2005. Spatial Augmented Reality: Merging Real and Virtual Worlds. Wellesley: Peters.

Boellstorff, Tom 2008. Coming of Age in Second Life. An Anthropologist Explores the Virtually Human. Princeton \& Oxford: Princeton University Press.

Bronner, Simon 2012. Practice Theory in Folklore and Folklife Studies. - Folklore 123, 1, 23-47 (http://dx.doi.org/10.1080/001558 7X.2012.642985).

Clough, Gill 2009. Geolearners: Informal Learning with Mobil and Social Technologies. Submitted for the Degree of Doctor of Philosophy in Educational Technology. Milton Keynes: Institute of Educational Technology.

Clough, Gill 2010. Geolearners: Location-Based Informal Learning with Mobil and Social Technologies. - IEEE Transactions on Learning Technologies 3, 1, 33-44 (http://dx.doi.org/10.1109/TLT.2009.39). 
Constanza, Enrico; Kunz, Andreas; Fjeld, Morten 2009. Mixed Reality: A Survey. - Lalanne, Denis; Kohlas, Jürg (toim). Human Machine interaction: Research Results of the MMI Program, LNCS 5440, 47-56 (http://www.t2i.se/pub/papers/springer_5440.pdf - 14.05.2013).

Einama, Kaido 2004. Aardeotsijad GPSiga. - Reisimaailm. Turismi, majutuse ja toitlustuse erialaajakiri 4, 40-43 (http://www.reisijutud. com/book/export/html/1232 - 14.05.2013).

Frasca, Gonzalo 2003. Simulation versus Narrative. Introduction to Ludology. - Wolf, Mark J. P.; Perron, Bernard (toim). The Video Game Theory Reader Video Game Theory Reader. New York: Routledge, 221-236 (http://interactive.usc.edu/blog-old/wp-content/ uploads/2011/01/Simulation_vs_Narrative.pdf - 14.05.2013).

Gram-Hansen, Lasse Burri 2009. Geocaching in a Persuasive Perspective. - Persuasive'09. Proceedings of the $4^{\text {th }}$ International Conference on Persuasive Technology, April 26-29, Claremont, California, ACM International Conference Proceeding Series, 350, [1-8], http:// portal.acm.org/citation.cfm?id=1541948.1541993 - 14.05.2013, doi: 10.1145/1541948.1541993).

Hawley, Francis Frederik 2010. Agon and Ecstasy: Transgression, Transformation, and Transcendence in Competitive Geocaching. - Deviant Behavior 31, 3, 225-250 (http://dx.doi.org/10.1080/01639620902855024). Huizinga, Johan 2003 [1938]. Mängiv inimene. Kultuuri mänguelemendi määratlemise katse. Tallinn: Varrak.

Ihamäki, Pirita Johanna 2012. Geocaching: Interactive Communication Channels Around the Game. - Eludamos. Journal for Computer Game Culture 6, 1, lk 133-152.

Juul, Jesper 2005. Half-real. Video games between real rules and fictional worlds. Cambridge: MIT Press.

Kalda, Mare 2007. Muistendid uues kontekstis - geopeituses. - Kõiva, Mare (koost). Paar sammukest XXIII. Eesti Kirjandusmuuseumi aastaraamat. Tartu: Eesti Kirjandusmuuseumi teaduskirjastus, 93-116 (http://www.folklore.ee/rl/pubte/ee/araamat/2007/4marekalda.pdf $-8.05 .2013)$.

Kaljundi, Linda 2011. Performatiivne pööre. - Marek Tamm (toim). Humanitaarteaduste metodoloogia: uusi väljavaateid. Gigantum humeris. Tallinn: TLÜ Kirjastus, 128-149.

Kalmre, Eda 2005. Laste-ja noortepärimus. - Hagu, Paul; Jaago, Tiiu; Järv, Risto; Kalmre, Eda; Krikmann, Arvo; Metsvahi, Merili; Särg, Taive; Valk, Ülo. Regivärsist netinaljadeni. Sissejuhatus rahvaluulesse. Tallinn: Koolibri, 163-179.

Kinnunen, Maarit 2010. Geojästi ja kymmenen komeaa kätköä. Geokätkö elamyksen lähteenä. Opinnäytetyö. Lahti: Lahden Ammattikorkeakoulu (https://publications.theseus.fi/bitstream/ handle/10024/16031/Kinnunen_Maarit.pdf?sequence $=1$ 14.05.2013). 
Klaus, Karin 2010. Geopeitus võimaldab aardeid leida igast Eesti nurgast. - Pärnu Postimees, 14. veebruar (http://www.parnupostimees. ee/224669/geopeitus-voimaldab-aardeid-leida-igast-eesti-nurgast/ $-7.05 .2013)$.

Lang, Valter 2005. Muinsuskaitsjad ja muinsuskütid. - Eesti Päevaleht, 24. mai (http://www.epl.ee/news/arvamus/valter-langmuinsuskaitsjad-ja-muinsuskutid.d?id=51011246 - 7.05.2013).

Magerkurth et al. $=$ Magerkurth, Carsten; Cheok, Adrian David; Mandryk, Regan L.; Nilsen, Trond 2005. Pervasive games: Bringing computer entertainment back to the real world. - Computers in Entertainment 3, 3, 1-19 (http://dx.doi.org/10.1145/1077246.1077257).

Malaby, Thomas 2007. Beyond Play. A New Approach to Games. - Games and Culture 2, 2, 95-113 (http://dx.doi.org/10.1177/1555412007299434).

McNeill, Lynne 2007. Portable Places: Serial Collaboration and the Creation of a New Sense of Place. - Western Folklore 66, 3/4, 281-300.

Milgram, Paul; Kishino, Fumio 1994. Taxonomy of Mixed Reality Visual Displays. - IEICE Transactions on Information and Systems, E77-D(12), 1321-1329 (http://etclab.mie.utoronto.ca/people/paul_dir/ IEICE94/ieice.html - 14.05.2013).

Montola, Markus 2012. Social Constructionism and Ludology: Implications for the Study of Games. - Simulation \& Gaming 43, 3, 300-320 (http://dx.doi.org/10.1177/1046878111422111).

Montola, Markus; Stenros, Jaakko; Waern, Annika 2009. Pervasive games: Theory and design. Amsterdam: Morgan Kaufmann.

Moore, Christopher 2011. The Magic Circle and the Mobility of Play. - Convergence. The International Journal of Research into New Media Technologies 17, 4, 373-387 (http://dx.doi.org/10.1177/1354856511414350).

Muuseumiöö 2011. "Öös on aardeid”. - Eesti Muuseumide Infokeskus (http:// www.muuseum.ee/et/kuum/muuseumioo/varasemad_muuseumioo/ muuseumioo_2011 - 14.05.2013).

Neustaedter, Carman; Tang, Anthony; Judge, Tejinder 2010. The Role of Community and Groupware in Geocache Creation and Maintenance. - Proceedings of the SIGCHI Conference on Human Factors in Computing Systems, 10-15 April 2010, Atlanta, Georgia. New York, 1757-1766 (http://hcitang.org/papers/2010-chi2010-geocaching.pdf14.05.2013; http://dx.doi.org/10.1145/1753326.1753590).

O'Hara, Kenton 2008. Understanding Geocaching Practices and Motivations. - Proceedings of the $26^{\text {th }}$ Annual SIGCHI Conference on Human Factors in Computing Systems, April 5-10, 2008, Florence, Italy, 1177-1186 (http://dx.doi.org/10.1145/1357054.1357239).

Putnam, Robert D. 2000. Bowling Alone: The Collapse and Revival of American Community. New York: Simon \& Schuster. 
Rebane, Kristjan 2012. Mäng on suure inimese töö. - Fututuba. Tulevikutrendide kohtumispaik. Eesti Arengufondi trendiblogi, 4. juuli (http://www.fututuba.ee/2012/07/mang-on-suure-inimese-too.html $-14.05 .2013)$.

Saarenpää, Siru 2009. “Mikä meitä oikein riivaa?” Geokätköilykyselyn yhteenveto. Kangasala (pdf-formaadis käsikiri autori valduses, alla laaditud aadressilt http://www.geocache.fi/materiaali/raportti.pdf).

Sadewasser, Thomas 2007. Geocaching-Abenteuer: Suchen und Verstecken mit GPS-Unterstützung. Berlin: Thomas Sadewasser.

Salen, Katie; Zimmerman, Eric 2004. Rules of Play. Game Design Fundamentals. London: MIT Press.

Sarpong, David; White, Gareth; Skinner, Heather 2012. Harnessing the Technology Wave for Tourism: drawing on the community of practice of Human Search Engines. - Paper, presented at the Academy of Marketing Conference July 2012: 'Marketing: Catch the Technology Wave'. University of Southampton's School of Management, [1-6] (http://marketing.conference-services.net/resources/327/2958/pdf/ AM2012_0129_paper.pdf - 14.05.2013).

Sarvas, Risto 2002. Geocacher stories. Research Paper. UC Berkeley: The School of Information Management and Systems (http://www.tlu. ee/ kpata/uusmeedia/geocache.pdf - 14.05.2013).

Schechner, Richard 1993. The Future of Ritual. Writing on Culture and Performance. London \& New York: Routledge.

Stenros, Jaakko; Waern, Annika; Montola, Markus 2012. Studying the Elusive Experience in Pervasive Games. - Simulation \& Gaming 43, 3, 339-355 (http://dx.doi.org/10.1177/1046878111422532).

Taylor, T. L. 2006. Play between Worlds. Exploring Online Game Culture. Cambridge: MIT Press.

Telaar, Daniel 2007. Geocaching: Eine kontextuelle Untersuchung der deutschsprahigen Geocaching-Community. Diplomarbeit im Studiengang Geographie, Münster: Westfälische WilhelmsUniversität Münster, Institut für Geographie (http://www.geocache. $\mathrm{ch}$ /daten/DA-Geocaching-2007-Telaar.pdf - 14.05.2013).

Vabrit, Maili 2002. Sünnipäev - endale ja teistele, korduv ja kordumatu. Jaago, Tiiu; Kõiva, Mare (koost). Dialoog privaatse ja avaliku elu vahel. Inimese ja keskkonna suhete peegeldus pärimuses. Elektroonilise konverentsi materjalid. Tartu: Eesti Kirjandusmuuseum, Tartu Ülikool, 66-73 (http://www.folklore.ee/rl/pubte/ee/cf/dialoog/ teema4-1.pdf - 14.05.2013).

Veenpere, Enn 2002. Aasta geopeitust Eestis. - Arvutimaailm 1, 41-43 (http://vana.geopeitus.ee/lisad/geopeitus.html - 14.05.2013). 
Vissel, Anu 1995. Traditsiooniline ja uuenduslik Eesti tänapäeva lastemängudes I. - Kõiva, Mare (toim). Lipitud-lapitud. Tänapäeva folkloorist. Tartu: Eesti Keele Instituut, Eesti Kirjandusmuuseum, 225-301 (http://www.folklore.ee/rl/pubte/ee/cf/ lipitud/Traditsiooniline.htm - 14.05.2013).

Willis, Katharine 2010. Hidden Treasure: Sharing Local Information. Aether. The Journal of Media Geography. Locative Media, Special Volume, 50-62 (http://geogdata.csun.edu/ aether/pdf/volume_05a/ willis.pdf - 14.05.2013).

\section{Viited geopeituse/geocachingu aaretele ja rubriikidele (aastaarv tähistab peitmise aastat)}

10 aastat $=10$ aastat geopeitust Eestis. http://www.geopeitus.ee/foorum/ read.php?1,13973,page $=1-14.05 .2013$.

Aastapäeva 2002. http://www.geopeitus.ee/aare/44 - 14.05.2013.

Enigma 2009. http://www.geopeitus.ee/aare/1221 - 14.05.2013.

Geopeitus kui mäng 2012. http://www.geopeitus.ee/aare/1769 - 14.05.2013.

GK 100 2012. http://www.geopeitus.ee/aare/1809 - 14.05.2013.

HE-aare 2001. http://www.geopeitus.ee/aare/1 - 14.05.2013.

Is Geocaching A ... sport? 2005. http://forums.groundspeak.com/GC/index. php? showtopic $=97773 \&$ st $=0 \& p=1473997 \&$ fromsearch $=1 \& \#$ ent ry1473997 - 14.05.2013.

Kes elab metsa sees? 2011. http://www.geopeitus.ee/aare/1589 - 14.05.2013. Koodimurdja 2010. http://www.geopeitus.ee/aare/1378 - 14.05.2013.

Mängureeglid. http://www.geopeitus.ee/wiki/reeglid - 14.05.2013.

Militaarne Hiiumaa 2005. http://www.geopeitus.ee/aare/401 - 14.05.2013.

Näpunäide 2010. http://www.geopeitus.ee/aare/1468 - 14.05.2013.

Puhatu 2005. http://www.geopeitus.ee/aare/343 - 14.05.2013.

"RASH" = The official "Geocaching Activity" acronym is now "RASH" 2002. http://forums.groundspeak.com/GC/index.php?showtopic=56489 14.05.2013.

Sõnastik [2001-2013]. http://www.geopeitus.ee/wiki/sonastik - 14.05.2013. Teolt tabatud 2005. http://www.geopeitus.ee/aare/329 - 14.05.2013.

Terevisiooni aare 2003. http://www.geopeitus.ee/aare/106 - 14.05.2013.

Vandi 2009. http://www.geopeitus.ee/aare/1131 - 14.05.2013.

Üllatus 2005. http://www.geopeitus.ee/aare/342 - 14.05.2013. 


\section{Summary}

\section{On the Play Element in Geocaching - the 21st Century Hobby}

Keywords: geocaching, pervasive games, game as a folklore genre

Since 2000, people all over the world have been engaged in geocaching - a game of hiding and seeking geocaches, in the course of which "treasures" are hidden and sought using navigational techniques and information technology. Caches are placed in concealed locations of physical space, the information that the participants jointly manage and renew is uploaded on the Internet where communication takes place. The aim of the research is to juxtapose geocaching with the features highlighted in classical ludology and also present other possibilities of categorisation, which have been applied in the previous studies of this recreational activity. While discussing the playfullness of geocaching, the author points out the peculiarities of the ludic traits of the hobby, in order to diversify folkloristic knowledge with new developments in the field of hidden treasures (which used to belong to traditional deeds and stories anyway) in the cultural situation of information era. The article focuses, above all, on geocaching in Estonia, yet also offers insights into the game on an international level. 


\section{MAAILM ja \\ MULTITASKING}

\section{Koostanud ja toimetanud MARE KÕIVA}

http://www.folklore.ee/rl/pubte/ee/cf/multi

ISBN 978-9949-544-01-1

Tartu 2014

Trükis ilmunud:

MAAILM ja MULTITASKING. Tänapäeva folkloorist 10.

Tartu 2014

Sarja peatoimetaja: Eda Kalmre

Kogumiku koostaja ja toimetaja: Mare Kõiva

Keeletoimetaja: Asta Niinemets

Kaanekujundus: Lilli-Krõõt Repnau

Küljendus: Diana Kahre

HTML: Diana Kahre

Trükist toetasid: teadusteema SF 0030181s08, ETF grant nr 8137 ja IUT22-5 ning Eesti Kultuurkapital.

E-raamatu valmimist toetas: EKKM14-344 Eesti keele, kultuuri ja folkloori kasutusalade laiendamine ja tutvustamine elektroonilistel infokandjatel.
(C) Mare Kõiva
(C) autorid
(C) EKM Teaduskirjastus 2014 